\title{
Morphological and mineralogical evidence for ancient bat presence in Cova des Pas de Vallgornera (Llucmajor, Mallorca, Western Mediterranean)
}

\author{
Antoni Merino ${ }^{1,2 *}$, Joan J. Fornós ${ }^{1,2}$, Antoni Mulet ${ }^{3}$, and Joaquín Ginés ${ }^{1,2}$ \\ ${ }^{1}$ Grup de Ciències de la Terra, Universitat de les Illes Balears, Carretera de Valldemossa, 07122 Palma, Illes Balears, Spain \\ ${ }^{2}$ Societat Espeleològica Balear, Carrer de Margarida Xirgu, 16. Baixos, 07011 Palma, Illes Balears, Spain \\ ${ }^{3}$ Federació Balear d'Espeleologia (FBE), C/Uruguai, s/n, 07010 Palma, Spain
}

\begin{abstract}
Cova des Pas de Vallgornera is a unique karst cave located at the Llucmajor coastal platform that stands out not only because of its length, more than $78 \mathrm{~km}$, but also for its particular morphological suite, richness and variety of speleothems and mineral infillings. Although the mineralogy of speleothems and minerals related to hypogene morphologies has been studied and described, the existence of minerals derived from guano deposits was still poorly investigated. The cave hosted bat colonies until the collapse of its natural entrances, circa 2.4 My ago, since then until its discovery in 1968, the cave remained sealed. These particular environmental conditions, kept along millennia, helped the interaction of guano-related leachates with the bedrock and clay deposits provoking dissolution and mineral precipitation. Moreover, thanks to the discovery of guano-associated cave minerals, it has also been possible to determine the presence of morphologies related to ancient guano deposits. In this paper, we report on features caused by bat's biomechanical erosion, bat claws and bat thumb marks and the influence of geobiological modifications caused by guano deposits on stalagmites and fallen boulders, haystack-shaped stalagmites, stalagmites covered in niches and crypto-corrosion features on fallen boulders. In addition, an array of guanorelated minerals is reported, being phosphates the most abundant mineral group identified, underlining the broad presence of fluorapatite from all the studied sites. Among the oxides and hydroxides, nordstrandite, gibbsite and todorokite are especially common. Finally, connections between microclimatic conditions in the cave and the location of bat roosting and breeding sites are discussed.
\end{abstract}

Keywords: littoral karstic cave, bats, scratches, guano deposits, phosphates, microclimate, ichnofossils Received 14 January 2019; Revised 30 April 2019; Accepted 30 April 2019

Citation: Merino A., Fornós J.J., Mulet A. and Ginés J., 2019. Morphological and mineralogical evidence for ancient bat presence in Cova des Pas de Vallgornera (Llucmajor, Mallorca, Western Mediterranean). International Journal of Speleology, 48 (2), 115-131. Tampa, FL (USA) ISSN 0392-6672 https://doi.org/10.5038/1827-806X.48.2.2247

\section{INTRODUCTION}

Cova des Pas de Vallgornera is located on the coast of Mallorca island, Western Mediterranean, and is an extensive maze cave partially drowned by brackish phreatic waters. With over $78 \mathrm{~km}$ it is the longest cave on the island (Merino et al., 2014a; Ginés et al., 2017). The cave lies in the natural area of Migjorn, in southern Mallorca, a coastal karstic region forming a tabular platform built by an Upper Miocene (Tortonian-Messinian) reef limestones sequence.

The speleogenesis of the cave is quite complex and is associated to three main drivers: dissolution in the freshwater-seawater mixing zone, the influence of surface recharge, and finally hypogene processes
(Ginés et al., 2009, 2014, 2017). The presence at the Galeria del Tragus of an important fossiliferous site containing among others, well-preserved remains of an extinct and endemic mammal (goat) attributed to Myotragus aff. kopperi helps to shed some light on the chronology of the deposit and thus, the sealing and isolation of the cave. In this sense, the absence of more modern species of Myotragus suggests that the collapse and sealing of the ancient natural entrances occurred around 2.4 My ago (Bover et al., 2014). Furthermore, some bat bones were also discovered at this site, proving that bats inhabited the cave before and until the collapse of the natural entrances. Currently, no natural entrances exist, being accessed by a single man-drilled well. Therefore, at present, the 
cave does not host bat colonies and thus is deprived of recent bat guano deposits.

Guano related morphologies and the resulting mineral assemblages have been described by many authors from caves worldwide that at present have open entrances and contain current or ancient bat guano deposits: Tarhule-Lips \& Ford (1998), Onac \& Veres (2003), Marincea et al. (2004), Onac et al. (2005, 2009), Bird et al. (2007), Lundberg \& McFarlane (2008, 2015),Wurster et al. (2010, 2015), Serra-Cobo et al. (2011, 2015), Giurgiu \&Tămaş (2013), Pogson et al. (2014), Puşcaş et al. (2014), Audra et al. (2016, 2017, 2019), McFarlane \& Lundberg (2018), Dandurand et al. (2019), etc. Nevertheless, Cova des Pas de Vallgornera represents a peculiar and uncommon site, it hosted bat colonies for an uncertain period of time, leaving their imprints and guano deposits until the entrances collapsed around 2.4 My ago. Since that moment and until its discovery, the cave did not experience major geomorphological changes allowing the preservation of bat-derived morphologies. Moreover, its special underground environmental conditions, temperature, relative humidity, $\mathrm{CO}_{2}$ concentration among others, favoured the precipitation of a variety of minerals associated with guano deposits. This paper describes bat-derived features and morphologies related to guano deposits found in the cave. Some of them can be classified as ichnofossils, being represented by bat scratches (bat claws and bat thumb marks) present in lenticular cross-section niches and ovoidshaped alcoves, whereas crypto-corrosion features originated on stalagmites and rock blocks are also described. Besides, guano-associated minerals have been identified and are also reported. Finally, the relationship between the microclimatic conditions that prevailed in the cave while it was inhabited by bats and the choice of roosting and breeding sites is discussed.

\section{METHODS}

First of all, a thorough search for bat claws and thumb marks was carried out not only at the already known places displaying bat scratches but also all around the cave system. Simultaneously, morphologies exhibiting marks (ovoid-shaped alcoves, lenticular niches) were identified as well as those displaying unusual cryptocorrosion features. The morphometry, depth and length of marks and thickness of the walls' weathered layer, were measured using a graduated ruler.

In order to evaluate and demonstrate the presence of guano-related cave minerals, more than 70 samples of minerals and weathering products were collected from all the studied sites. Particular interest was devoted to sample earthy materials accumulated on ovoid-shaped alcoves, lenticular cross-section niches, wall ledges, crypto-corrosion features and walls. Samples were collected with the permission of the Direcció General d'Espais Naturals i Biodiversitat del Govern Balear.

Mineralogy was determined by X-ray diffraction on raw powder unoriented samples using a Brucker D8 Advance analytical X-ray system at the Universitat de les Illes Balears (Serveis Científico-Tècnics), with CuKa radiation at $40 \mathrm{kV} / 40 \mathrm{~mA}$ and $3-70^{\circ}$ (2-theta), step $0.02^{\circ}$, time per step $1 \mathrm{~s}$, conditions. Semi-quantitative mineral calculations based on the obtained peak areas were carried out using the Diffrac_EVA 4.1 software. Selected samples were analysed by EDX (Bruker X-Falsh Detector 4020) and/or observed by Scanning Electron Microscope (SEM, HitachiE S-3400N).

\section{GENERAL AND MORPHOGENETIC SETTINGS}

Cova des Pas de Vallgornera is an outstanding karst cave located at the Llucmajor coastal platform that stretches along the southern part of Mallorca Island and developes in flat-lying Upper Miocene reef carbonates (Merino et al., 2014a; Ginés et al., 2014, 2017). The cave is roughly disposed in three main tiers; the studied and sampled locations are all of them placed in the passages of the upper tier that forms the northernmost landward part of the cave (Fig. 1).

The morphology of the cave system is very diverse showing a rich assortment of solutional features of different characteristics, together with a remarkable crystalline decoration characterized by great speleothem diversity (Merino et al., 2014b). From the point of view of its planimetric pattern, the Cova des Pas de Vallgornera exhibits two well-differentiated settings (Ginés et al., 2014). On one hand, spongework mazes and collapse chambers form the seaward sections of the cave, developed in the very porous reef-front facies of the Upper Miocene carbonates; on the other hand, an important network of joint-guided passages characterises the innermost landward parts, which were excavated in the less permeable back-reef facies (Fig. 1).

Regarding the morphogenesis of this complex karst cave, three speleogenetic pathways are envisaged (Ginés et al., 2009, 2014, 2017). Besides the coastal mixing processes occurring in the littoral limestone areas, a basal hypogene recharge linked to the geothermal phenomena existing in the Llucmajor area has been documented (López \& Mateos, 2006; López, 2007; Onac et al., 2014). Finally, a noticeable meteoric recharge, evidenced by means of thick detritic deposits related to an ancient blocked entrance, should be mentioned. The chronology of the main speleogenetic processes falls back, at least, to mid-Pliocene times, on the basis of the vertebrate palaeontological remains recovered in the innermost sectors of the cave.

\section{PRESENCE OF BAT-RELATED FEATURES}

Bat claws and thumb scratches were first identified on the walls of Galeria d'en Pau (Fig. 1) and one of the passages that communicates the former gallery with Galeria del Gran Canyó. Currently, these peculiar morphologies have also been observed at the following sites: a gallery aligned to the SE of Galeria del Gran Canyó, a passage situated parallel to Galeria del Tragus, in the Sector Nord, and at the Jacuzzi, a vast rimstone pool that temporarily dams up fresh water, located to the NE branch of Galeria de les Columnes. 


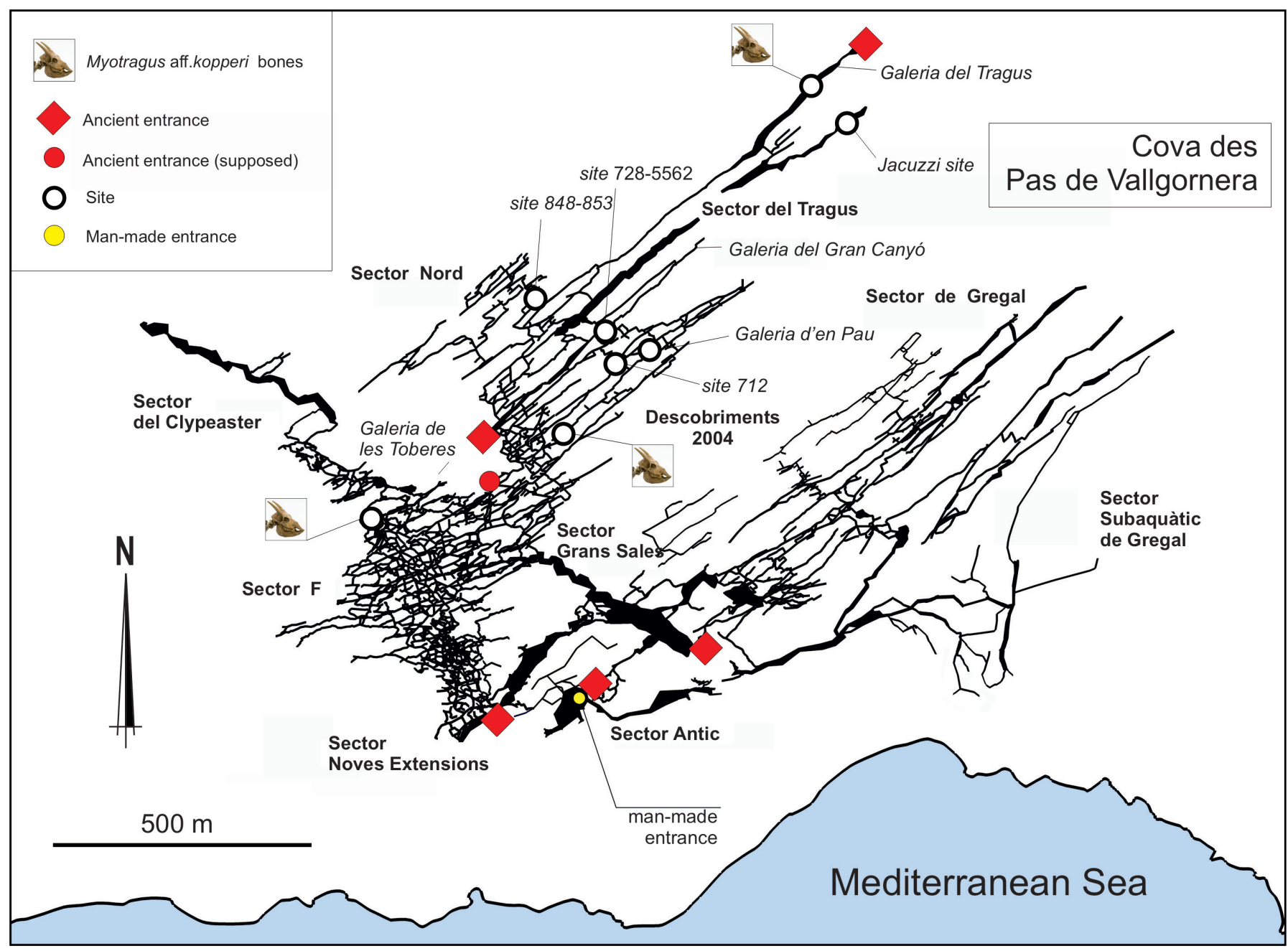

Fig. 1. Survey of Cova des Pas de Vallgornera showing the distribution of the described sites, as well as the ancient and currently sealed entrances.

It must be stressed that nowadays there is no open entrance to the cave, neither bat colonies in it. Although no natural access exists, the existence of small holes and cracks that allow a certain air exchange with the outside cannot be completely ruled out. The only accessible entrance is a 6-m deep drilled cesspit, which is sealed with a special gate. The excavation of this well in 1968 , led to the discovery of the cave (Merino et al., 2014a).

In order to identify the different described locations containing distinctive morphologies within the cave, they have been named using the suitable gallery name or survey station numbers for those passages without specific names.

\section{Locations with bat related morphologies}

Galeria d'en Pau site. Along the Galeria d'en Pau, a section of about $25 \mathrm{~m}$ in length presents batrelated morphologies, mainly composed of bat claws and thumb marks covering walls and ceiling affected by weathering processes. This segment of the gallery (Fig. 2A), whose walls are affected by a weathering process up to $1 \mathrm{~mm}$ in depth, shows a marked ceiling channel exhibiting abundant bat scratches.

Site 712. The passage that connects Galeria d'en Pau with Galeria del Gran Canyó, displays about 40 $\mathrm{m}$ of its length marked with bat-related morphologies: claws and thumb marks, being narrower than Galeria d'en Pau (Fig. 2B). Walls are quite weathered, showing an increasing alteration and thickness to the $\mathrm{NE}$ of the gallery, thickness also varies from $1 \mathrm{~mm}$ in the upper half section up to $4 \mathrm{~mm}$ in the ceiling. This site contains some interesting examples of ovoid-shaped alcoves and lenticular cross-section niches.

Site 728-5562. Another area with bat scratches is a corridor aligned to the Galeria del Gran Canyó that starts at a junction and runs to the SW for roughly 90 $\mathrm{m}$. The upper half of the weathered walls and ceiling are covered with abundant light brown to brown multicoloured deposits that overlay an altered rock layer with a fluctuating thickness between $1 \mathrm{~mm}$ and $30 \mathrm{~mm}$, decreasing from $\mathrm{NE}$ to the SW (Fig. 2C). In a marginal small corridor, the ceiling shows a deep altered layer of $30 \mathrm{~mm}$ in thickness, while on the walls it reaches up to $10 \mathrm{~mm}$.

Site 848-853. Two passages parallel to the SW section of Galeria del Tragus also present bat-related morphologies. The first one (Fig. 3A), exhibits bat scratches along $25 \mathrm{~m}$, walls are profusely cracked and deeply weathered (Fig. 3B). The upper half of the gallery shows an altered rock layer that ranges from 10 to $30 \mathrm{~mm}$ in depth, which in turn is overlain by a thin brownish to yellowish brown multicoloured deposit.

The second gallery, parallel to the former one, shows bat scratches along $30 \mathrm{~m}$. Ceiling and walls of the upper third of passage are strongly altered, showing layers of weathered rock up to $50 \mathrm{~mm}$ in thickness; this deep weathering causes the fall of the thickest sheets (Fig. 3C). 


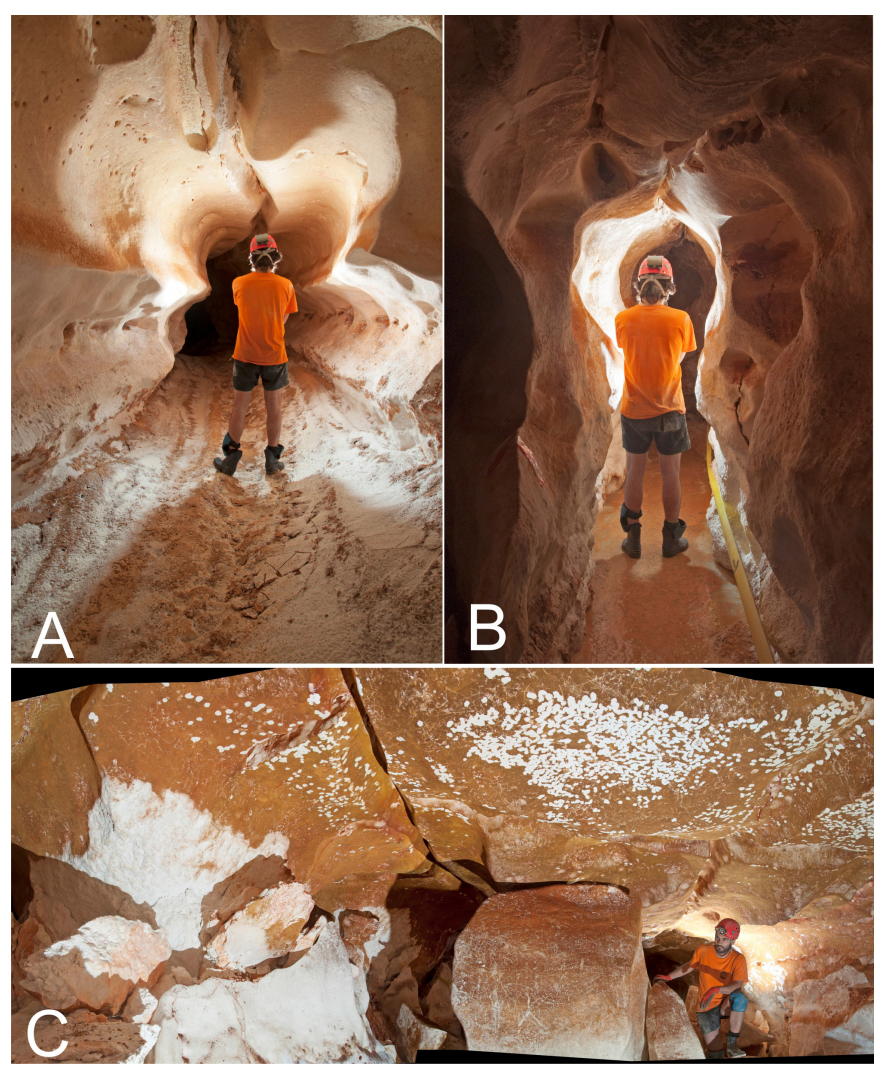

Fig. 2. A) Cross-section at Galeria d'en Pau showing its peculiar shape. Almost two thirds of the lower section of the gallery are coated with a white mineral crust thicker at the bottom and thinning upwards. The upper section shows some bat scratches on the wall and ceiling; B) Site 712. Tight passage between Galeria d'en Pau and Galeria del Gran Canyó whose walls and ceiling exhibit abundant bat scratches in the upper half of the gallery. The ceiling has a layer of weathered rock $4 \mathrm{~mm}$ thick, while its thickness decreases to the walls; C) Site 7285562. Panoramic photo of the junction at the beginning of the corridor aligned to the Galeria del Gran Canyó. Walls and ceiling are covered with a thick brown yellowish multicoloured deposit where clear bat scratches are displayed. The boulder roughly in the center of the photo exhibits profuse scratches all around it, which attests that this rock was already in place while bats were using the cave as a shelter. On the contrary, the white slabs on the left occurred subsequently to the sealing of the cave because of the lack of marks on them.

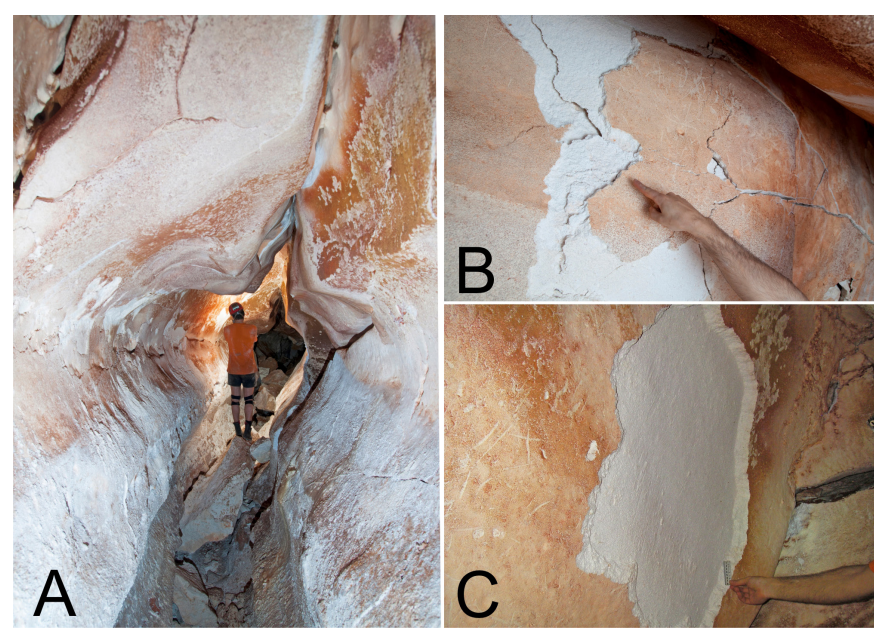

Fig. 3. A) Structurally controlled rectilinear passage at site 848-853. The lower half section is varnished with a white mineral crust mainly composed of calcite, while the upper section is cracked and altered, with weathered layers of up to $30 \mathrm{~mm}$ in thickness. Brownish to yellowish multicoloured deposits are clearly seen along the gallery; B) Site 848. Cracked wall displaying a thick altered layer of rock overlain by a thin multicoloured coating which in turn shows bat marks; C) Site 848-853. Stretch of wall exhibiting an extremely weathered process that penetrates deep into the bedrock. The detached $50 \mathrm{~mm}$ altered layer allows showing the white bedrock surface devoid of bat scratches, whereas the rest of the stained surface displays different bat-related marks.
Jacuzzi site. This is the richest area containing bat scratches that are also among the best preserved. It is located to the NE branch of Galeria de les Columnes, parallel to Galeria del Tragus. The Jacuzzi is a $140-\mathrm{m}$ long passage, with an average width of $8 \mathrm{~m}$; it can be divided into two different parts. The first one shows a massive accumulation of collapsed roof rocks and wall slabs; the ceiling and some walls are covered with light-brown to yellowish multicoloured deposits (Fig. 4A). A section of the ceiling, about $4 \mathrm{~m}$ above the gallery, displays a large concentration of bat thumb marks (Fig. 4B). The second one is formed by a huge two-terraced rimstone pool (Fig. 4C).
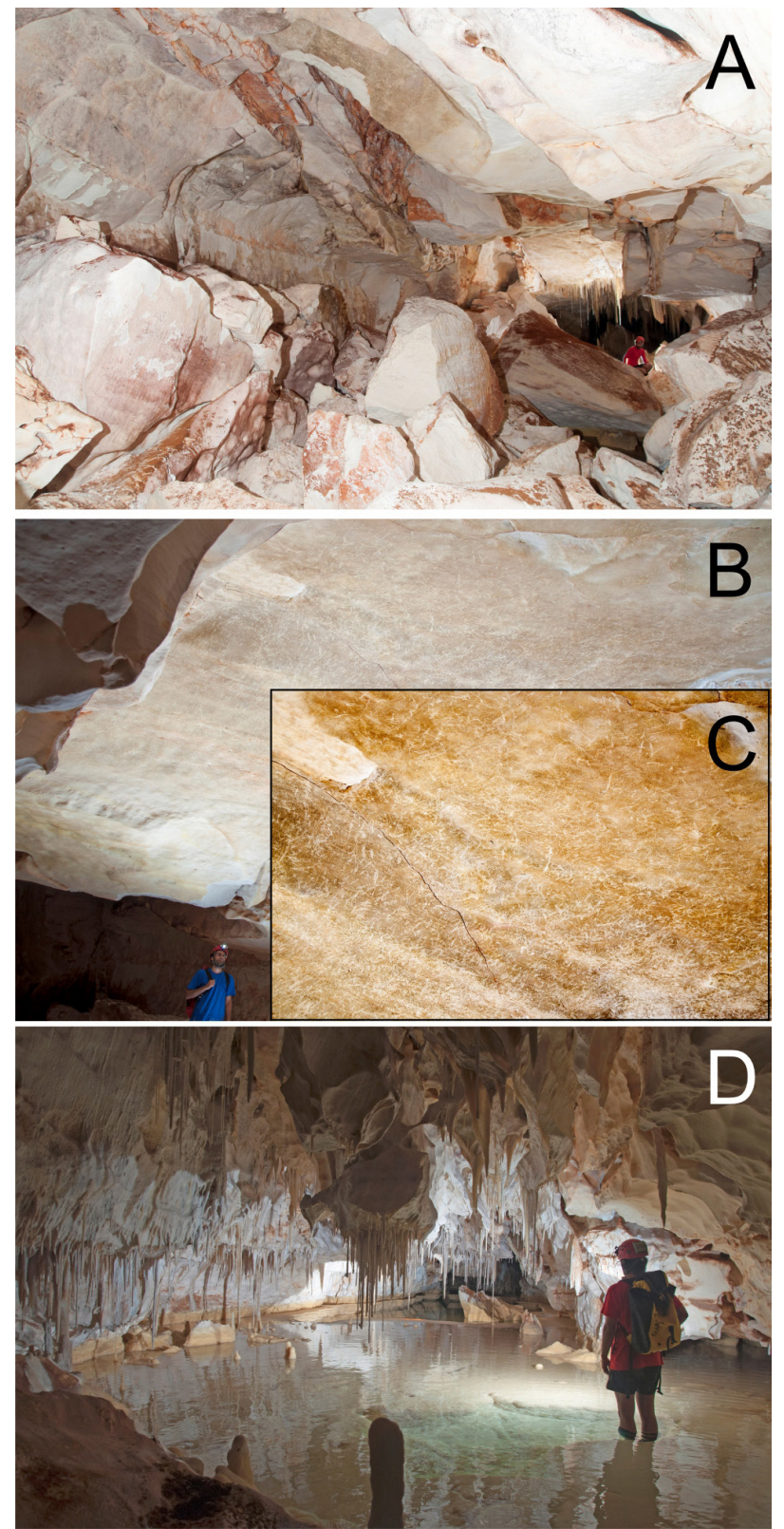

Fig. 4. A) First section of the Jacuzzi site. Massive accumulation of boulders floors the passage after breakdown processes that happened before the cave was sealed. Brownish deposits can be seen covering fallen rocks; the left-hand wall displays multicoloured deposits, exhibiting patches of white bedrock surfaces where the weathered layer has fallen down; B) Flat ceiling utterly covered mainly in bat thumb marks, differences in colour highlight the profusion of scratches, general setting; C) Marks in detail. Jacuzzi site; D) Last section of the first rimstone dam at the Jacuzzi site. Right at the center of the photo, the second and deep rimstone dam can be clearly seen. The gallery is coated and ringed with a yellowish band of calcite crystals that completely seals it, allowing the accumulation of fresh water. Ceiling and walls present an irregular surface with some speleothems. 


\section{DESCRIPTION OF BAT-DERIVED FEATURES AND DEPOSITS}

The peculiar morphologies associated to the presence of bats in Cova des Pas de Vallgornera can be organised into two categories, depending on the mechanism of alteration and its effect: (1) features caused by biomechanical erosion affecting walls and ceilings and (2) guano-related features (Audra et al., 2016, 2017, 2019).

As a consequence of the long-term cave evolution since it was isolated from the surface and of the deep alteration processes that have acted and still act in the cave, it is perfectly plausible that some of these morphologies were displayed in other areas, being currently obscured by weathering processes, coated by mineral crusts, or destroyed by collapse episodes.

\section{Biomechanical erosion}

Mechanical erosion morphologies are by far, the most abundant and conspicuous in the cave; they have been observed in all of the known and described sites (Tables 1, 2). The identified and reported morphologies are: bat scratches (bat claws and bat thumb marks) along walls and ceilings, or concentrated in lenticular niches and ovoid-shaped alcoves. The genesis of the last two mentioned features is not related directly to bat activity, but bats benefited from the preexistence of voids and pockets to use them as shelters causing erosion and, in the case of ovoid-shaped alcoves, producing clear modifications. These preexistent corrosion morphologies, that exist in other areas with no bat presence recorded, are the result of complex corrosion processes linked to the mixing zone between fresh meteoric water and sea water, in the coastal fringe of carbonate terrains (Gràcia et al., 2009a, 2009b).

\section{Bat claws and thumb marks}

Apparently, these trace fossils have not been described in detail before. Audra et al. (2016, 2017) refer to bat claws as a mechanical weathering agent acting when bats cling to the walls using their claws. The only comments we have found in the published literature of anything comparable is by Tarhule-Lips and Ford (1998) who briefly mention the lack of claw marks on the walls of bell holes. Two types of marks can be differentiated, the ones left by bat thumbs (Fig. 5A) and the ones left by bat claws (Fig. 5B-D). As far as claw marks, they are formed by two more or less parallel rectilinear marks composed each of them, by up to 5 parallel grooves (Fig. 6A); on some occasions and due to the thickness of altered bedrock, it is not possible to distinguish any groove, being replaced by a blurred mark that also exists for thumb marks (Fig. 6C). They proliferate on walls and mainly on ceiling channels where they become longer when the channel is wider. This morphology is also abundant near cracks or wall ledges where bats tried to hang (Fig. 6D). In places, it is possible to distinguish both feet claws from the same individual making a distinctive v-shaped mark (Fig. 6E). Marks left by bat thumbs (Fig. 6B) are caused when bats flutter around trying to grasp at walls or ceiling using their thumbs, they are formed by a single, more or less curvilinear, uneven groove. In general, grooves are more obvious when they affect an altered surficial layer that shows some differences in color with the layer below.

Table 1. Measurements of thumb and claw marks taken at each of the locations.

\begin{tabular}{|c|c|c|c|c|c|c|c|}
\hline & Location & $\begin{array}{l}L \max \\
(\mathbf{m m})\end{array}$ & $\begin{array}{l}L \min \\
(\mathbf{m m})\end{array}$ & $\begin{array}{l}\text { Width } \\
\text { (mm) }\end{array}$ & $\begin{array}{c}\text { Thickness } \\
\text { of altered } \\
\text { layer (mm) }\end{array}$ & V-shaped & $\begin{array}{c}L \text { average } \\
(\mathbf{m m})\end{array}$ \\
\hline \multirow{9}{*}{$\begin{array}{l}\text { Thumb } \\
\text { marks }\end{array}$} & $\begin{array}{c}\text { Galeria d'en } \\
\text { Pau }\end{array}$ & 190 & 60 & $1-2$ & $1-2$ & ----- & 125.0 \\
\hline & Site 712 & 130 & 35 & $1-2$ & $1-2$ & ----- & 82.5 \\
\hline & Site 728 & 110 & 35 & $1-2$ & $1-2$ & ----- & 72.5 \\
\hline & Site 5562 & 150 & 60 & $1-2$ & $1-2$ & ----- & 105.0 \\
\hline & Site 848 & 110 & 50 & $1-2$ & $2-30$ & $\begin{array}{l}---- \\
\end{array}$ & 80.0 \\
\hline & SIte 853 & 110 & 30 & $1-2$ & $2-20$ & ----- & 70.0 \\
\hline & $\begin{array}{c}\text { Jacuzzi } \\
\text { beginning }\end{array}$ & 190 & 40 & $1-2$ & $4-10$ & ------ & 115.0 \\
\hline & Jacuzzi center & 170 & 50 & $1-2$ & $2-50$ & ------ & 110.0 \\
\hline & Jacuzzi back & 180 & 20 & $1-2$ & $1-2$ & ------ & 100.0 \\
\hline \multirow{9}{*}{$\begin{array}{l}\text { Claws } \\
\text { marks }\end{array}$} & $\begin{array}{c}\text { Galeria d'en } \\
\text { Pau }\end{array}$ & 95 & 40 & 10 & $1-2$ & yes & 67.5 \\
\hline & Site 712 & 70 & 35 & 10 & $1-2$ & yes & 52.5 \\
\hline & Site 728 & 50 & 30 & 10 & $1-2$ & yes & 40.0 \\
\hline & Site 5562 & 90 & 40 & 10 & $1-2$ & yes & 65.0 \\
\hline & Site 848 & 85 & 45 & 10 & $2-30$ & yes & 65.0 \\
\hline & SIte 853 & 80 & 35 & 10 & $2-20$ & yes & 57.5 \\
\hline & $\begin{array}{c}\text { Jacuzzi } \\
\text { beginning }\end{array}$ & 90 & 40 & 10 & $4-10$ & yes & 65.0 \\
\hline & Jacuzzi center & 80 & 40 & 10 & $2-50$ & yes & 60.0 \\
\hline & Jacuzzi back & 90 & 40 & 10 & $1-2$ & yes & 65.0 \\
\hline
\end{tabular}


Table 2. Dimensions of lenticular and ovoid shape features identified at each of the locations, along with thickness of altered rock layer and deposits.

\begin{tabular}{|c|c|c|c|c|c|c|c|c|}
\hline & \multirow[b]{2}{*}{ Location } & \multirow{2}{*}{$\begin{array}{l}\text { Width } \\
\text { (mm) }\end{array}$} & \multirow{2}{*}{$\begin{array}{c}\text { Depth } \\
\text { (mm) }\end{array}$} & \multirow{2}{*}{$\begin{array}{c}\text { Height } \\
\text { (mm) }\end{array}$} & \multicolumn{3}{|c|}{ Thickness of altered layer (mm) } & \multirow{2}{*}{$\begin{array}{c}\text { Deposit } \\
\text { thickness } \\
\text { (mm) }\end{array}$} \\
\hline & & & & & lateral & $\begin{array}{l}\text { at the } \\
\text { back }\end{array}$ & ceiling & \\
\hline \multirow{9}{*}{$\begin{array}{l}\text { Lenticular } \\
\text { shape }\end{array}$} & Galeria d'en Pau & ----- & ----- & ----- & ----- & ----- & ----- & ----- \\
\hline & Site 712 & 899 & 542 & 398 & 5 & 3 & 15 & 10 \\
\hline & Site 728 & ----- & ----- & ----- & ----- & ----- & ----- & ----- \\
\hline & Site 5562 & 421 & 314 & 170 & 5 & 10 & 20 & 5 \\
\hline & Site 848 & ----- & ----- & ----- & ----- & ----- & ----- & ----- \\
\hline & SIte 853 & ----- & ----- & ----- & ----- & ----- & ----- & ----- \\
\hline & Jacuzzi beginning & 506 & 287 & 229 & $5-7$ & 0 & 7 & 5 \\
\hline & Jacuzzi center & ------ & ------ & ------ & ------ & ----- & ----- & ----- \\
\hline & Jacuzzi back & 662 & 838 & 233 & $1-2$ & 0 & 12 & 2 \\
\hline \multirow{9}{*}{$\begin{array}{l}\text { Ovoid } \\
\text { shape }\end{array}$} & Galeria d'en Pau & 459 & 391 & 574 & 10 & 15 & 30 & 2 \\
\hline & Site 712 & 296 & 523 & 773 & 20 & 25 & 30 & 2 \\
\hline & Site 728 & ----- & ----- & ----- & ----- & ----- & ----- & ----- \\
\hline & Site 5562 & 326 & 293 & 965 & 30 & 20 & 30 & 20 \\
\hline & Site 848 & 636 & 474 & 595 & 15 & 20 & 30 & 2 \\
\hline & Site 853 & ----- & ----- & ----- & ----- & ----- & ----- & ----- \\
\hline & Jacuzzi beginning & ----- & ------ & ----- & ----- & ----- & ----- & ----- \\
\hline & Jacuzzi center & ----- & ----- & ----- & ----- & ----- & ----- & ----- \\
\hline & Jacuzzi back & ----- & ----- & ----- & ----- & ----- & ----- & ----- \\
\hline
\end{tabular}

Features present in lenticular cross-section niches and ovoid-shaped alcoves

Lenticular-shaped niches are elliptical concavities of centimetric order which develop on bedding planes or horizontal levels where a change in the bedrock's lithology occurs; Gràcia et al. (2009a) call these features wall pockets. They can be found in main galleries and lateral sinuses. The upper half of this morphology is devoid of sediments, while the ceiling and walls exhibit mainly bat claw marks; the lower section has a sloping floor covered by a thin layer of sediments composed of different minerals and particles of rock (Fig. 7A).

Ovoid-shaped alcoves develop on minor vertical joints that previously presented some voids or

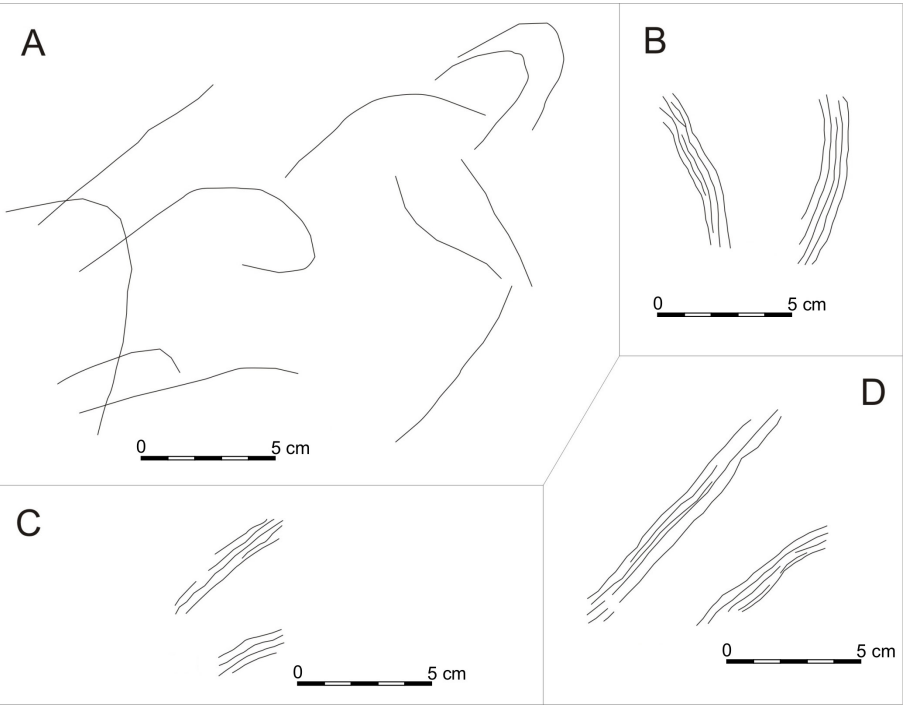

Fig. 5. Sketch showing the main bat scratches trend; A) Different curvilinear and arbitrary bat thumb marks; B) Characteristic V-shaped mark left by bat claws displaying clear and parallel 5 grooves; $C$ and D) Uneven bat claw marks of different length showing a more parallel pattern between claws and the distinctive small grooves. concavities that facilitated the use of these features as roosting sites. This morphology displays an ovoid cross-section, which is commonly culminated in its highest part by an open conical cap (Fig. 7B). The former inceptive cavity was altered and highly modified by bat claws and bat thumbs when bats fluttered around while trying to cling to walls or ceiling surface, causing an important mechanical erosion and the fall of rock fragments that accumulate on an inclining surface at the bottom of this structure (Fig. 7C). Finally, a positive influence of condensationcorrosion processes caused by bat breathing and heating cannot be excluded in the weathering of the rock surface.

\section{Morphologies related to guano deposits}

All of these morphologies have been exclusively identified at the Jacuzzi site, encompassing features originated on stalagmites: haystack-shaped structures and stalagmites covered in niches; and crypto-corrosion morphologies developed on fallen rocks and boulders.

\section{Features originated on stalagmites}

The haystack-shaped stalagmites exhibit smooth and corroded surfaces that allow to see the inner crystallized structure; some of them are quite hemispherical, being between 0.5 and $0.7 \mathrm{~m}$ in diameter (Fig. 8A). They are developed mainly on a huge boulder that in turn, is covered by highly corroded flowstones that show several stages of calcite precipitation.

One stalagmite carved by niches has also been identified at the Jacuzzi site, being located in the central area. It displays a particularly corroded side with some alveoli embedded in the upper third, the rest of the formation that is not coated by vadose 


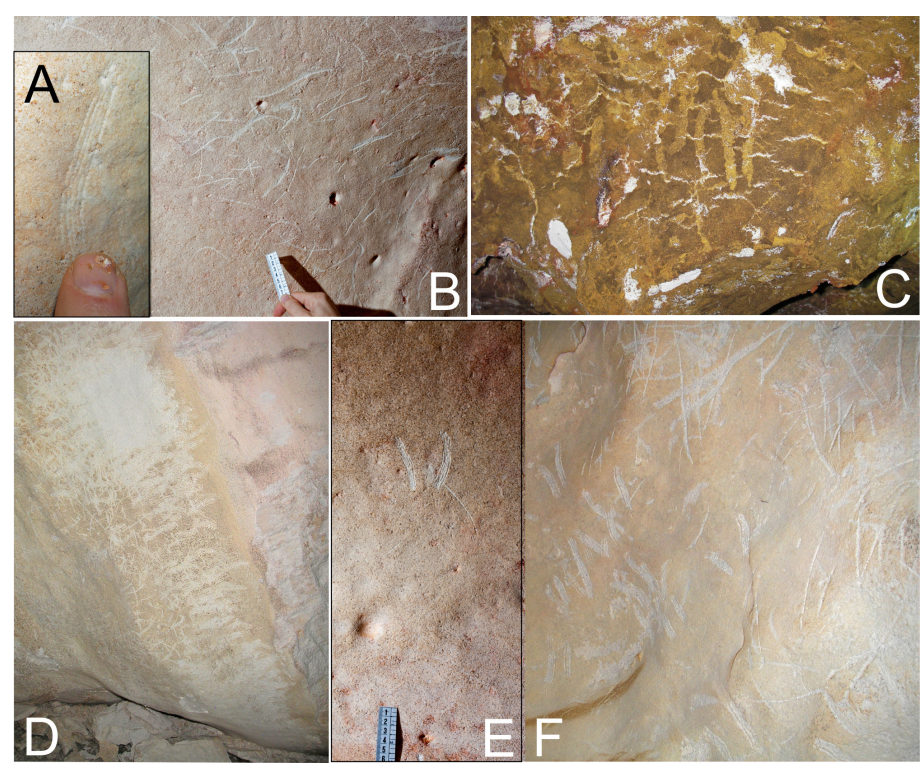

Fig. 6. A) Bat claw mark showing 5 clear parallel grooves on the wall of site 853 ; B) Assemblage of curvilinear bat thumb marks covering a wall at Galeria d'en Pau. Scale in centimetres; C) Blurred claw marks on a boulder wall covered with colourful deposits that contain among others minerals, fluorapatite and nordstrandite. Site 728 . Width of the photo is $35 \mathrm{~cm}$; D) Tilted fallen slab, formerly part of a cracked wall. The upper third band of the tilted rock shows a heavily marked surface, where it is possible to observe a profusion of claw marks and numerous thumb marks below. The white spot situated at the upper part of the photo exhibits an area covered in claw marks. Jacuzzi site. Width of the photo is $1 \mathrm{~m}$; E) Peculiar V-shaped morphology produced when a bat tried to cling to the wall with its claws and failed to do it, leaving these visible scratches, Galeria d'en Pau; F) V-shaped morphologies at the Jacuzzi site. Scale in centimetres.

crystallizations exhibits massive abraded layers (sliceshaped) of calcite, some of them protruding from the main body (Fig. 8B).

\section{Crypto-corrosion features}

Smooth elongated grooves have been recognized on tilted fallen limestone boulders, reaching up to $2 \mathrm{~m}$ in length, about $4 \mathrm{~cm}$ width and $2 \mathrm{~cm}$ deep. They are carved quite parallel to each other, showing a more complex upper area with smoother interconnected incuts; grooves get more marked and deeper to the bottom of the boulder. It is possible to observe curved grooves caused by a shift in the surface direction (Fig. 8C).

Juxtaposed morphologies also occur, being composed of small rills, up to $20 \mathrm{~cm}$ in length, intermingled with concave voids that would resemble guano pots (Audra et al., 2016). As in the previously described features of this site, the substantial calcite crystallization that took place as a consequence of the large accumulation of water, covered and disguised all patterns situated below the reached maximum level of the rimstone pool (Fig. 9).

Some boulders show more conspicuous guttershaped morphologies that might also be related to these features, but due to the intricate morphological variety of patterns that carve the bedrock, the evidence is perhaps not conclusive.

\section{Guano-associated cave minerals}

The cave mineral assemblage of the analysed samples is composed predominantly of calcite and silicates (Table 3), containing occasionally phosphates, oxides and hydroxides (Tables 4,5$)$. Most samples are mixtures of 3 or more minerals.

Deposits found covering boulders, rock shelves, alcoves and niches have a paste-like consistency and feel slippery and somehow greasy to touch, with colours ranging from light brown to black, whereas multicoloured deposits exhibit a fluffy and porous structure that forms thin mats on walls and ceilings of passages. Many of these deposits are yellowish brown, but they may also be pinkish or black. A total of 34 samples yielded phosphates, whereas supplied some atypical oxides and hydroxides (most of these mineral assemblages associated with detrital material, quartz, goethite, muscovite, kaolinite, etc.). The most abundant phosphate occurrence is fluorapatite, which has been identified at all investigated sites, followed by hydroxylapatite. The existence of uncommon phosphate minerals, like kribergite, wyllieite, and qingheiite, is suspected but not yet confirmed. The presence of Al-hydroxides (nordstrandite, gibbsite) and $\mathrm{Mn}$-oxide (todorokite) is also reported.

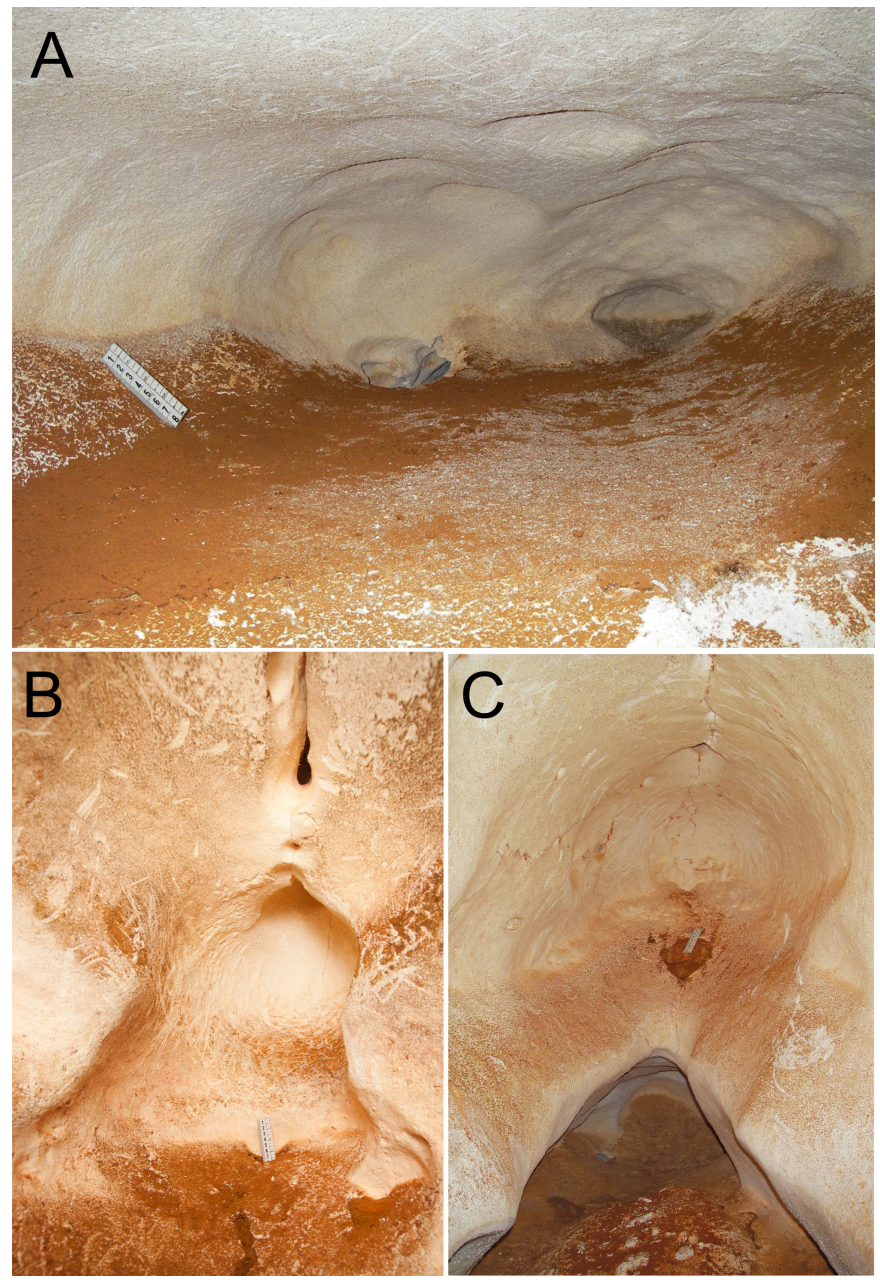

Fig. 7. A) Lenticular cross-section niche whose walls and ceiling exhibit abundant bat marks. The floor presents a brownish pasty deposit that contains fluorapatite. Scale in centimetres. Jacuzzi site. Scale in centimetres; B) Characteristic ovoid-shaped alcove located at Site 712 . The altered layer is totally eroded away from walls by bat thumbs and claws, while at the bottom of this morphology, hydroxylapatite has been identified intermingled with brown clay material. Scale in centimetres; C) Ovoid-shaped alcove at Galeria d'en Pau, showing bat thumb and claw marks along its walls and ceiling. The brownish deposit right in the center of the photo contains, among other minerals, fluorapatite. Below the slit, an evident accumulation of bedrock particles and some clayey materials can be seen. Rule for scale is $8 \mathrm{~cm}$. 


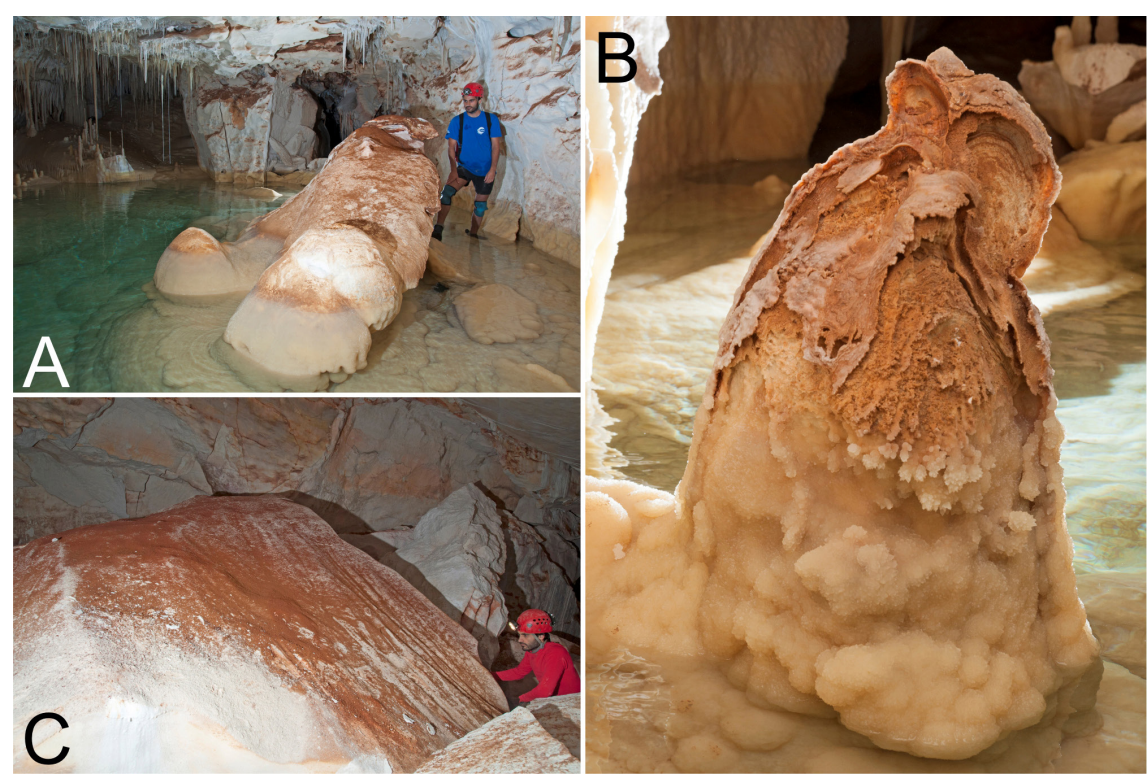

Fig. 8. A) Haystack-shaped stalagmites developed on a fallen boulder located in a massive rimstone dam at the Jacuzzi site. Fluorapatite has been identified in the brownish deposit that covers the surface of the boulder. A pool spar crystallized band lines the whole pool and marks the upper water level reached by percolating water; B) Stalagmite displaying deep organic corrosion processes that causes the formation of small niches, exposing its inner structure. Spar crystallizations obscure most of the stalagmite surface, making infeasible the examination of the whole formation. Jacuzzi site. Scale: diameter at the base of the stalagmite is $50 \mathrm{~cm}$; C) Elongated grooves that resemble rinnenkarren features, developed on a tilted fallen boulder located at the beginning of the Jacuzzi site. The brownish deposit that covers most of the rock is enriched in fluorapatite.

Although gypsum is one of the most common minerals related to bat guano deposits, it has only been reported at Galeria d'en Pau.

\section{DISCUSSION}

Caves containing guano-related features and associated minerals currently host (or have hosted) bat colonies that have permitted the accumulation of important guano deposits and caused a biogenicallymediated corrosion and the resulting mineral assemblages. All of these caves share a common denominator, they have present-day open entrances that allow access not only to bats but also to cavers and researchers, at the same time they all have current or relict bat guano deposits.

In this sense, Cova des Pas de Vallgornera represents a unique and exceptional site, inhabited by bats for an uncertain period of time, leaving their imprint and guano deposits until it was naturally blocked, circa $2.4 \mathrm{My}$ ago (Bover et al., 2014, Ginés et al., 2014). During the Quaternary, the studied areas did not undergo major geomorphological changes: the longterm stability of the underground environment has allowed the preservation of bat-derived features (Fig. 10).

Nevertheless, flooding of the cave as a consequence of global glacioeustatic variations that affected the
Mediterranean basin must be taken into consideration (Lorscheid et al., 2017; Raymo et al., 2018; among others). The sector where the cave develops is considered tectonically stable (Pomar \& Ward, 1995; Just et al., 2011). The lack of important bat bone deposits could be a consequence of the decay of the organic matter contained in guano accumulations, the influence of moisture, and the resulting aggressive leachates that would have decomposed the bone remains.

Furthermore, the persisting stability of the cave environment is sometimes transgressed by development phases. The absence of thick or more extensive phosphate deposits could be linked to three main factors acting together or separately: changing environmental conditions (moisture, drippings, etc), specific physico-chemical conditions (variations of $\mathrm{pH}$, availability of certain cations that would have promoted greater solubility among phosphates), and the consecutive inundations that involved the cave along the highstand Pleistocene periods (removing phosphates and minerals mostly by dissolution).

Although currently there are no recognizable guano traces in the cave, its former presence can be inferred from several mineral species identified, mainly belonging to the chemical group of phosphates (fluorapatite, hydroxylapatite). The special underground environmental conditions that prevailed over the centuries, temperature, high relative humidity, $\mathrm{CO}_{2}$ concentration, lack of outside influences, limited percolating water, permitted not only the precipitation of a variety of minerals, but also their evolution to more stable mineral species under these conditions.

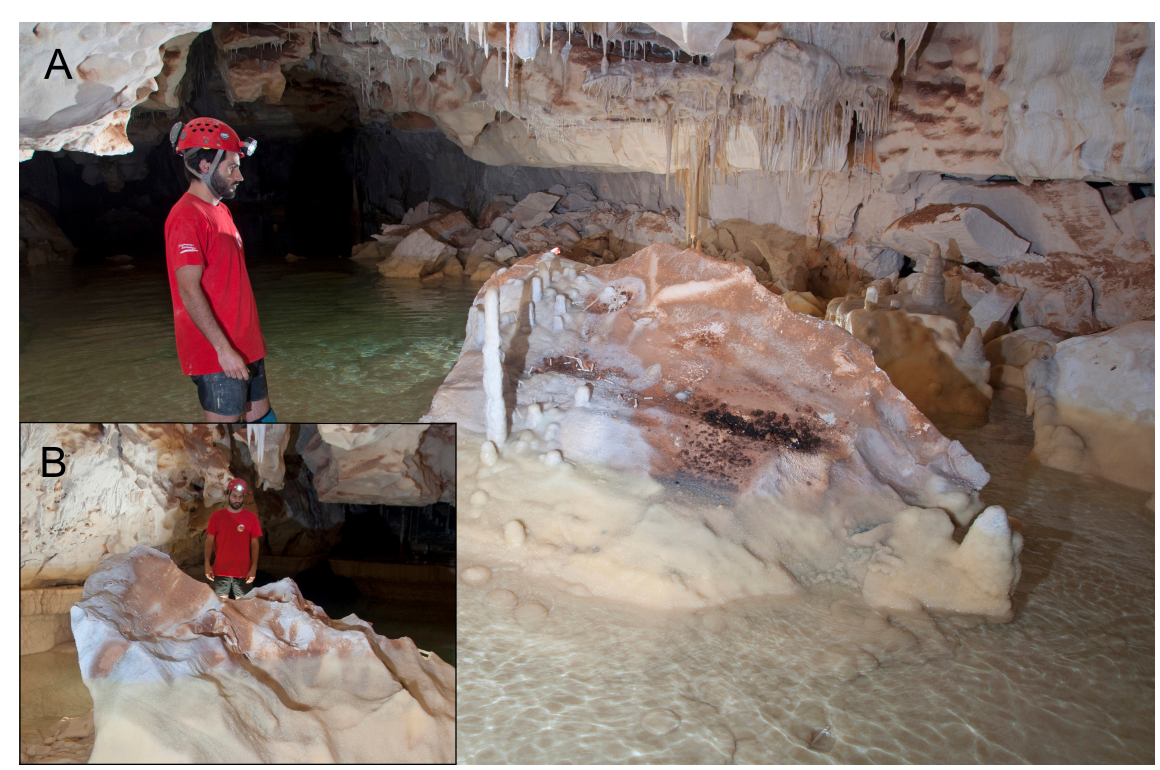

Fig. 9. Juxtaposed morphologies which might be related to guano deposits at the back of the Jacuzzi site. A) Boulder whose surface could have been altered due to guano accumulation. The black deposit is composed of fluorapatite and clayey materials; B) Boulder exhibiting a quite uneven surface which could have been reworked by guano deposits. Small rills and concave features can clearly be distinguished. 
Table 3. List of clay minerals and carbonates (no fluorine content) found at each location.

\begin{tabular}{|c|c|c|c|c|c|}
\hline Location & Sample & Mineral/Series & $\begin{array}{c}\text { Associated } \\
\text { mineral/series }\end{array}$ & Color & Other minerals/Series \\
\hline $\begin{array}{c}\text { Galeria d'en } \\
\text { Pau }\end{array}$ & VL-M286 & Calcite & Goethite & Brown & Quartz, Kaolinite \\
\hline \multirow{4}{*}{ Site 712} & VL-M245 & Calcite & Muscovite/Illite & Brown & Kaolinite \\
\hline & VL-M246 & Calcite & $\begin{array}{c}\text { Illite/ } \\
\text { Montmorillonite } \\
\end{array}$ & Black & Kaolinite \\
\hline & VL-M247 & Calcite & Kaolinite & Brown & Quartz \\
\hline & VL-M288 & Muscovite/Illite & Goethite & Brown & \\
\hline \multirow{2}{*}{ Site 728} & VL-M248 & Calcite & Kaolinite & Yellow-Brown & \\
\hline & VL-M289 & Calcite & none & Yellow-Green & \\
\hline \multirow{5}{*}{ Site 5562} & VL-M249 & Goethite & Kaolinite & Yellow-Brown & \\
\hline & VL-M251 & Muscovite/Illite & Goethite & Brown & \\
\hline & VL-M252 & Calcite & Goethite & Black & \\
\hline & VL-M253 & Goethite & Kaolinite & Brown & Muscovite/Illite \\
\hline & VL-M290 & Calcite & Illite & Brown & Kaolinite \\
\hline \multirow{2}{*}{ Site 848} & VL-M254 & Calcite & Kaolinite & Brown & Muscovite/Illite \\
\hline & VL-M255 & Calcite & none & Light Brown & \\
\hline \multirow{6}{*}{ SIte 853} & VL-M259 & Illite & Calcite & Reddish & Kaolinite/Illite \\
\hline & VL-M260 & Calcite & none & Yellow-Brown & \\
\hline & VL-M261 & Calcite & none & Brown & \\
\hline & VL-M262 & Illite & Kaolinite & Brown-Reddish & \\
\hline & VL-M291 & Illite & Kaolinite & Reddish & \\
\hline & VL-M292 & none & none & & just Fluorapatite and Nordstrandite \\
\hline \multirow{11}{*}{ Jacuzzi back } & VL-M196 & Quartz & Calcite & Black & Muscovite/Illite \\
\hline & VL-M209 & Quartz & none & Black & \\
\hline & VL-M210 & Calcite & Quartz & Black & \\
\hline & VL-M263 & Goethite & Muscovite/Illite & Brown & Quart, Kaolinite \\
\hline & VL-M264 & Dolomite & Quartz & Black & \\
\hline & VL-M265 & Calcite & Quartz & Black & \\
\hline & VL-M266 & Calcite & none & Black-Brown & \\
\hline & VL-M267 & Goethite & Quartz & Brown & \\
\hline & VL-M268 & Goethite & Montmorillonite & Brown & \\
\hline & VL-M271 & Calcite & none & Black & \\
\hline & VL-M272 & Calcite & Quartz & Brown & \\
\hline \multirow{7}{*}{ Jacuzzi center } & VL-M197 & none & none & & just Fluorapatite and Kribergite \\
\hline & VL-M198 & Calcite & none & Pinkish & \\
\hline & VL-M206 & Calcite & none & Pinkish & \\
\hline & VL-M207 & Calcite & none & Pinkish & \\
\hline & VL-M215 & Calcite & Muscovite/Illite & Ochre & Kaolinite \\
\hline & VL-M220 & Calcite & none & Brown & \\
\hline & VL-M22 1 & Calcite & none & Brown & \\
\hline \multirow{3}{*}{$\begin{array}{c}\text { Jacuzzi } \\
\text { beginning }\end{array}$} & VL-M280 & Illite & none & Pinkish & \\
\hline & VL-M281 & Calcite & none & Orange & \\
\hline & VL-M283 & Illite & Kaolinite & Brown & \\
\hline
\end{tabular}

On the contrary, this environmental scenario would have prevented the widespread preservation of other guano-related minerals like gypsum because of their high solubility (Onac \& Vereş, 2003; Onac et al., 2005; Puşcaş et al., 2014), occurring only in small quantities at Galeria d'En Pau.

\section{Microclimatic constraints}

The distribution of the studied and described locations containing bat-related features was not a random choice for bats; actually, they can shed some light on the microclimatic conditions that prevailed at that time in certain areas within the cave. In fact, all bat-derived morphologies caused by biomechanical erosion are present where walls and ceilings display a layer of weathered rock, with various thickness. This demonstrates that, by the time bats inhabited the cave, weathering processes were already active and had a key role in facilitating the biomechanical erosion produced by bats. 
The area where the cave is located has an average annual temperature of approximately $18^{\circ} \mathrm{C}$ (López, 2007), therefore the cave should have roughly the same ambient temperature. On the contrary, the Llucmajor area presents geothermal activity whose origin is the shallowest aquifer of the Llucmajor platform and the Campos Basin. A deep investigation drilling, $700 \mathrm{~m}$ deep, revealed water temperatures up to $70^{\circ} \mathrm{C}$ at the deepest section (López et al., 2004; Mateos et al., 2005; López, 2007). Boop et al. (2014) reported mean air temperatures at Sector Antic of $19.50^{\circ} \mathrm{C}$, whilst mean phreatic water temperature was $19.68^{\circ} \mathrm{C}$. At Sector del Tragus, a remote section within the cave, we have detected phreatic water and air temperatures of $20.40^{\circ} \mathrm{C}$ (unpublished).

Table 4. List of more significant mineral species identified at each of the locations, describing the site where it was deposited and its colour.

\begin{tabular}{|c|c|c|c|c|c|}
\hline Location & Sample & Mineral & $\begin{array}{l}\text { Associated } \\
\text { mineral }\end{array}$ & Color & Location \\
\hline \multirow{2}{*}{$\begin{array}{l}\text { Galeria d'en } \\
\text { Pau }\end{array}$} & VL-M242 & Gypsum & none & Translucent & on passage floor \\
\hline & VL-M286 & Fluorapatite & none & Brown & at the base ovoid-shaped feature \\
\hline \multirow{4}{*}{ Site 712} & VL-M245 & Hydroxylapatite & none & Brown & at the base ovoid-shaped feature \\
\hline & VL-M246 & Hydroxylapatite & Wyllieite & Brown & multicolored on the ceiling \\
\hline & VL-M247 & Hydroxylapatite & Fluorapatite & Brown & on floor lenticular shaped feature \\
\hline & VL-M288 & Fluorapatite & none & Brown & on floor lenticular shaped feature \\
\hline \multirow[b]{2}{*}{ Site 728} & VL-M248 & Fluorapatite & none & Yellow-Brown & multicolored on boulder's wall \\
\hline & VL-M289 & Fluorapatite & $\begin{array}{c}\text { Nordstrandite/ } \\
\text { Gibbsite }\end{array}$ & Yellow-Green & multicolored on the ceiling \\
\hline \multirow{5}{*}{ Site 5562} & VL-M249 & Fluorapatite & none & Yellow-Brown & on lateral terrace \\
\hline & VL-M251 & Fluorapatite & none & Brown & at bottom juxtaposed feature \\
\hline & VL-M252 & Fluorapatite & none & Black & multicolored on wall upper part \\
\hline & VL-M253 & Fluorapatite & none & Brown & on floor lenticular shaped feature \\
\hline & VL-M290 & Fluorapatite & none & Brown & on floor lateral passage \\
\hline \multirow{2}{*}{ Site 848} & VL-M254 & Nordstrandite & none & Brown & at the base ovoid-shaped feature \\
\hline & VL-M255 & Fluorapatite & Qingheiite & Light Brown & multicolored on wall upper part \\
\hline \multirow{6}{*}{ Site 853} & VL-M259 & Nordstrandite & none & Reddish & on boulder \\
\hline & VL-M260 & Fluorapatite & Qingheiite & Yellow-Brown & multicolored on the ceiling \\
\hline & VL-M261 & Hydroxylapatite & none & Brown & on lateral shelf \\
\hline & VL-M262 & Fluorapatite & Nordstrandite & Brown-Reddish & on lateral shelf \\
\hline & VL-M291 & Nordstrandite & none & Reddish & on boulder \\
\hline & VL-M292 & Nordstrandite & Fluorapatite & Brown & on boulder under previous sample \\
\hline \multirow{11}{*}{ Jacuzzi back } & VL-M 196 & Hydroxylapatite & none & Black & on boulder (fallen boulder) \\
\hline & VL-M209 & Hydroxylapatite & Chromceladonite & Black & on lateral shelf under calcite layer \\
\hline & VL-M210 & Hydroxylapatite & none & Black & on lateral shelf under calcite layer \\
\hline & VL-M263 & Hydroxylapatite & none & Brown & on lateral shelf \\
\hline & VL-M264 & Fluorapatite & Fluorapatite & Black & on lateral shelf under calcite layer \\
\hline & VL-M265 & Hydroxylapatite & none & Black & on lateral shelf under calcite layer \\
\hline & VL-M266 & Nordstrandite & $\begin{array}{l}\text { Todorokite/ } \\
\text { Birnessite }\end{array}$ & Black-Brown & on boulder, at lateral passage \\
\hline & VL-M267 & Todorokite & none & Brown & on boulder, at lateral passage \\
\hline & VL-M268 & Fluorapatite & none & Brown & on lateral terrace, at lateral passage \\
\hline & VL-M271 & Fluorapatite & none & Black & on boulder in the middle upper gour \\
\hline & VL-M272 & Fluorapatite & none & Brown & on boulder, right side "cylinders" \\
\hline \multirow{7}{*}{$\begin{array}{l}\text { Jacuzzi } \\
\text { center }\end{array}$} & VL-M197 & Fluorapatite & Kribergite & Ochre & multicolored on wall upper part \\
\hline & VL-M198 & Fluorapatite & none & Pinkish & multicolored on wall layer under \\
\hline & VL-M206 & Fluorapatite & none & Pinkish & multicolored on the ceiling \\
\hline & VL-M207 & Fluorapatite & none & Pinkish & multicolored on the ceiling \\
\hline & VL-M215 & Fluorapatite & none & Ochre & on boulder (fallen) haystack boulder \\
\hline & VL-M220 & Fluorapatite & none & Brown & multicolored on the ceiling \\
\hline & VL-M221 & Hydroxylapatite & none & Brown & on boulder below ceiling \\
\hline \multirow{3}{*}{$\begin{array}{c}\text { Jacuzzi } \\
\text { beginning }\end{array}$} & VL-M280 & Nordstrandite & none & Pinkish & on boulder \\
\hline & VL-M281 & Nordstrandite & none & Orange & on boulder \\
\hline & VL-M283 & Fluorapatite & none & Brown & on boulder with crypto-lapiaz \\
\hline
\end{tabular}


All of these data show an anomalous difference of between $+1.68^{\circ} \mathrm{C}$ and $+2.40^{\circ} \mathrm{C}$, higher than would be expected, strongly suggesting a feeble ongoing geothermal influence in the cave. It is probable that this environmental geothermal-driven situation was already prevailing at the time when the cave was used as roosting and breeding shelter, consequently providing a suitable cave environment for bats.

Bats inhabiting temperate zones are known to make migratory movements, changing roosting sites on a seasonal basis, trying to reach suitable cave environments for each season (McNab, 1982; Baudinette et al., 1994; Rodrigues \& Palmeirin, 2008). In this respect and taking into consideration these higher than normal mean temperatures in the cave, it is possible that it was not used as hibernation site, but as spring-maternity and/or maternity-mating roost instead (Rodrigues \& Palmeirin, 2008). These authors suggest that warmer hibernaculum temperature is advantageous for pregnant bat females to allow embryos to develop; furthermore, the newly born bats require even higher temperatures to stimulate fast growth.

Bats prefer isolated breeding and nursery roosts whose requirements are rather precise in terms of temperature and humidity, avoiding unstable environmental areas affected by airflows or close to cave entrances, among others (Ransome, 1990). Apart from the artificial access to the cave, five ancient entrances have been identified so far, two of them in the studied area within the innermost sectors of the cave; both of them are today naturally sealed from the external surface (Fig. 1). The first one is located at the north-easternmost section of Galeria del Tragus, (Fig 1) and the other situated to the south-westernmost point of Galeria del Gran Canyó, both of them on a NE-SW axis, approximately one kilometre away from each other. The most significant ancient entrance, from a chronological point of view, is the one located at the end of Galeria del Tragus, due to the discovery of a rich, well-preserved fossiliferous deposit of vertebrate remains (Bover et al., 2014), that include some Chiroptera bones attributed to Rhinolophus aff. mehelyi and Pipistrellus sp. The finding, among other mammal bones, of fossil remains belonging to the extinct and endemic goat Myotragus aff. kopperi, and the absence of more modern species of this genus, suggests that the chronology of the collapse of this natural entrance occurred during the Early Pleistocene, circa 2.4 My ago, or even before (Bover et al., 2014). The other ancient entrances have not yet provided clear geochronological data in order to determine whether they collapsed sooner or later than the Early Pleistocene; nevertheless, the remains of two other individuals also belonging to Myotragus aff. kopperi have been clearly identified, one of them at Galeria d'en Pau, and the other at a remote area within Sector F (Fig 1). All of this and the lack of more modern Myotragus species, especially Myotragus balearicus which is common in many caves in Mallorca, might indicate that all of them collapsed around the same period of time. This means the cave belonged to a closed cave system from the Early Pleistocene onward, until its discovery in 1968.

Table 5. Identified guano-derived mineral species and their chemical formulae.

\begin{tabular}{|c|c|c|}
\hline Chemical Group & Mineral & Chemical formula \\
\hline Sulfates & Gypsum & $\mathrm{CaSO}_{4} \cdot 2 \mathrm{H}_{2} \mathrm{O}$ \\
\hline \multirow{4}{*}{ Phosphates } & Fluorapatite & $\mathrm{Ca}_{5}\left(\mathrm{PO}_{4}\right)_{3} \mathrm{~F}$ \\
\cline { 2 - 3 } & Hydroxylapatite & $\mathrm{Ca}_{5}\left(\mathrm{PO}_{4}\right)_{3}(\mathrm{OH})$ \\
\cline { 2 - 3 } & Wyllieite & $\left(\mathrm{Na}, \mathrm{Ca}, \mathrm{Mn}^{2+}\right)\left(\mathrm{Mn}^{2+}, \mathrm{Fe}^{2+}\right)\left(\mathrm{Fe}^{2+}, \mathrm{Fe}^{3+}, \mathrm{Mg}\right) \mathrm{Al}\left(\mathrm{PO}_{4}\right)_{3}$ \\
\cline { 2 - 3 } & Qingheiite & $\mathrm{Na}_{2}\left(\mathrm{Mn}^{2+}, \mathrm{Mg}, \mathrm{Fe}^{2+}\right)\left(\mathrm{Al}, \mathrm{Fe}^{3+}\right)\left(\mathrm{PO}_{4}\right)_{3}$ \\
\cline { 2 - 3 } & Kribergite & $\mathrm{Al}_{5}\left(\mathrm{PO}_{4}\right)_{3}\left(\mathrm{SO}_{4}\right)(\mathrm{OH})_{4} \cdot 4\left(\mathrm{H}_{2} \mathrm{O}\right)$ \\
\hline \multirow{4}{*}{ Oxides /Hydroxides } & Birnessite & $\mathrm{Na}_{4} \mathrm{Mn}_{14} \mathrm{O}_{27} \cdot 9 \mathrm{H}_{2} \mathrm{O}$ \\
\cline { 2 - 3 } & Nordstrandite & $\mathrm{Al}(\mathrm{OH})_{3}$ \\
\cline { 2 - 3 } & Gibbsite & $\mathrm{Al}(\mathrm{OH})_{3}$ \\
\cline { 2 - 3 } & Todorokite & $\left(\mathrm{Mn}^{2+}, \mathrm{Ca}, \mathrm{Mg}\right) \mathrm{Mn}_{3}{ }^{4+} \mathrm{O}_{7} \cdot \mathrm{H}_{2} \mathrm{O}$ \\
\hline \multirow{4}{*}{ Silicates } & Chromceladonite & $\mathrm{K} \mathrm{Cr} \mathrm{Mg}\left(\mathrm{Si}_{4} \mathrm{O}_{10}\right)(\mathrm{OH})_{2}$ \\
\hline
\end{tabular}

The mass of air inside the cave is not stagnant: important air movements have been documented in the cave, not only at the access hatch, but also when the access door is sealed while researchers are inside. On this latter situation, a soft measured breeze at a speed of $1 \mathrm{~m} / \mathrm{s}$, at a narrowing, was able to cause soda straw stalactites to vibrate. For a period of 18 months a wind measurement programme was carried out at the cave entrance. The results showed changes in airflow direction, from outflow to inflow or viceversa, with distinct time delays between one situation and the other, this happening every day, with airflow velocities ranging from 1 up to $6 \mathrm{~m} / \mathrm{s}$.

The variation of airflow direction and airflow speed are a response of the cave system to air pressure differences between the cave microclimate and the outside atmosphere. These key factors would point out to classify the cave as a barometric cave from a speleoclimatologic point of view, with air flowing into the same direction simultaneously at all entrances of the cave due to barometric influences (Conn, 1966; Pflitsch \& Piaseck, 2003, Pflitsch et al., 2010). In addition, these authors also conclude that equilibrium between the outside pressure and the pressure inside the cave hardly ever lasts too long, causing an almost constant airflow.

This permanent airflow configuration and the influence of outside temperature and humidity changes would have obliged bats to choose specific sites to roost and breed. 

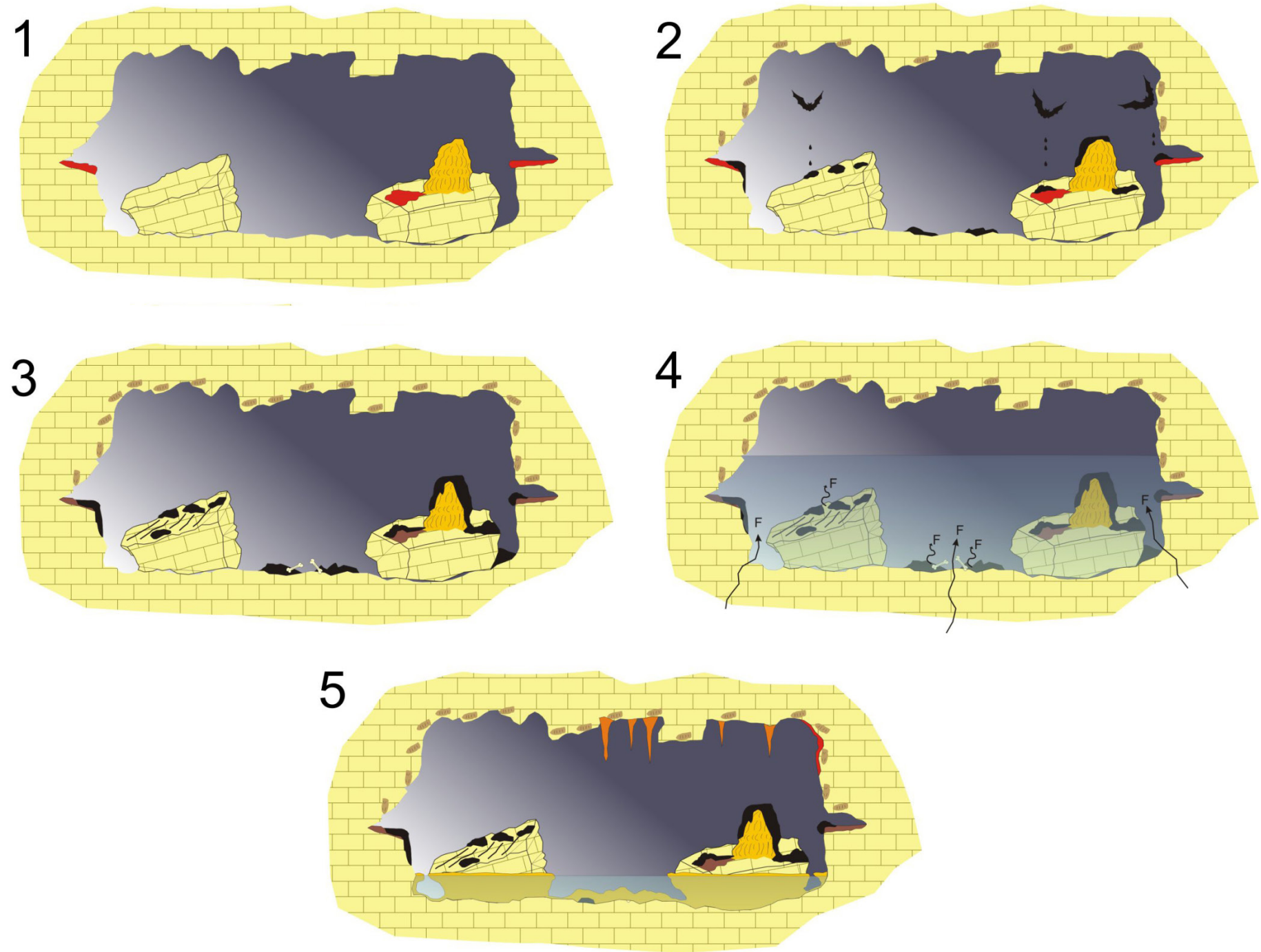

Fig. 10. 1) Situation after the main speleogenetic processes and before being inhabited by bats (in red colour, clays); 2) Bats use the cave as a roosting and breeding site. Accumulation of guano deposits and biomechanical erosion. Decomposition of guano starts in a moist environment causing acidic leachates that react with the bedrock and clayey deposits precipitating phosphates and other cave minerals; 3) Simultaneously, the acidic conditions carve elongated grooves on fallen boulders and cause important corrosion features on stalagmites. After the sealing of the main entrances of the cave, bats disappear; accumulation of bat bones that are dissolved by the highly aggressive leachates that release among other products fluorine; 4) During Pleistocene sea high-stands the cave is partially drowned interspersing hypogene episodes that carry fluorine that reacts with already precipitated phosphates; 5) When the phreatic level drops as a consequence of sea low-stands, the upper tier of the cave, where these passages are located, dries out. Carbonate precipitation processes start as a result of seeping vadose water, provoking the deposition of a calcite band that lines the bottom of the gallery, allowing the formation of freshwater ponds.

All sites with bat-related morphologies and guanoassociated minerals, discovered so far, are not situated in the main galleries of this sector, Galeria del Gran Canyó and Galeria del Tragus, but at a certain distance away and at well-protected locations within them. Bats are sensitive to changes in their environment, therefore they choose small alcoves (lenticular-shaped niches and ovoid-shaped morphologies) to be more isolated and at more stable climatic conditions. At the time when most of the entrances remained open, the microclimatic conditions inside the cave could have been quite extreme during episodes of great and quick atmospheric pressure changes. The presence of calcified splashes on walls of a tight sector in Galeria del Tragus is strongly suggestive of an ancient inward powerful draught of air (Fig. 11). The moving air mass would have circulated relatively smoothly from the massive ancient entrance, located at the end of this gallery, through the vast first hundredths of meters of the passage until reaching the beginning of the narrowing. At this point, the air would have accelerated, gaining strength and being capable of causing spatter-shaped morphologies where walls were covered in pasty altered bedrock.

\section{Morphologies associated to guano deposits}

The genesis of these morphologies is a consequence of the accumulation of bat feces on the bedrock or on stalagmites; at these spots corrosion takes place under the guano surface at the rock-guano interface etching out these features (Audra et al., 2016, 2017, 2019).

Other possible corrosive processes that could have been involved in shaping these morphologies, could be ruled out for the following reasons. Firstly, all of these morphologies have been exclusively identified at the Jacuzzi site. Secondly, the section of the gallery that exhibits these features presents walls and ceiling covered with abundant bat claws and thumb marks. At the same time, the ceiling directly above these peculiar features does not normally have visible dripping points or stalactites. Thirdly, most of the 


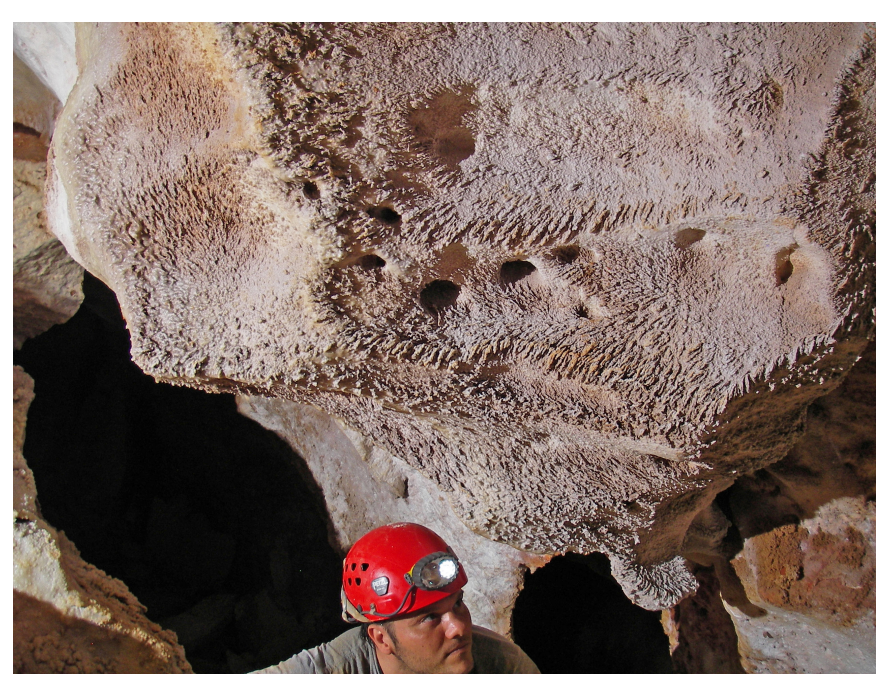

Fig. 11. Calcified splashes oriented by strong airflow covering a wall surface at a narrowing at Galeria del Tragus. The radial organization of elongated spatters developing on concave areas is quite obvious.

described bat-related morphologies show phosphate deposits on them (crypto-corrosion features). In the case of the stalagmite carved by niches, the process is highly likely to have been complemented by condensation-corrosion under vadose conditions (Audra et al., 2016, 2017, 2019).

\section{Mechanical erosion features}

The existence of bat-derived features (bat claws and thumb marks) caused by biomechanical erosion on walls and ceilings, could possibly be explained because their surfaces were already affected by deep weathering processes which would be related to condensation-corrosion processes. The latter happening when the temperature of the cave walls is below the dew point of the cave air; water condensates and reaches an equilibrium with the partial pressure of $\mathrm{CO}_{2}$ of the cave atmosphere, provoking an aggressive solution that is able to dissolve limestone (Dreybrodt et al., 2005). During the period the cave entrances remained opened and bats inhabited in there, the already mentioned air movements (cold winter air from the surface) would have increased the condensation-corrosion rate causing a strong and faster weathering that affected walls and ceilings, allowing bat biomechanical erosion. Eventually, the progressive closing of the cave entrances would have reduced the tendency for further condensation to lower levels, fossilizing bat scratches.

Table 1 shows the measurements obtained from each of the described morphologies, maximum and minimum figures of claw and thumb marks are on average calculated on 6 samples for each of them. The layer of altered bedrock thickness can be quite variable ranging from 1-2 $\mathrm{mm}$ (Galeria d'En Pau, site 712, site 728-5562) up to $50 \mathrm{~mm}$ (site 848-853, Jacuzzi site). At the same time, it greatly varies along the section of the galleries: the upper half shows an increase of up to 50 $\mathrm{mm}$ in thickness, whilst the lower half is in most of the occurrences covered by a calcite coating.

As for thumb marks length, they range from $20 \mathrm{~mm}$ up to $190 \mathrm{~mm}$, being more abundant on walls. The width of each of the claw marks is always constant, $10 \mathrm{~mm}$, with lengths ranging from 30 up to $95 \mathrm{~mm}$.
The mechanical erosion caused by bat claws and to a lesser extent bat thumbs, will depend on the characteristics and degree of alteration of the bedrock.

Seemingly, there is a direct connection between the degree of bedrock alteration, the thickness of the weathered layer, and the existence of, on the one hand, well-preserved clear grooves or, on the other, blurred marks (whether they are claws or thumb marks). Generally, well-marked and distinctive grooves are present with layers of altered rock between 1-10 mm in depth. On some occasions, when bats tried to clutch at walls, they were capable of causing significant mechanical erosion that virtually deprived the wall or ceiling of altered material (Fig. 7B).

Allegedly, the degree of bedrock weathering also facilitates the configuration of ovoid-shaped alcoves that are concentrated at locations where the altered bedrock sheet ranges from 10 to $30 \mathrm{~mm}$ (Table 2).

The inclination angle of the floor of ovoid-shaped alcoves and lenticular-shaped niches determines the deposit bulkiness that accumulates, being much higher at the latter due to their quite horizontal floor (Table 2). Although being classified as ovoid-shaped feature, the one described from site 5562, exhibits a more bell-shaped form, surrounded by other corrosion features, which could explain the presence of an anomalous thicker deposit.

\section{Mineralogy}

The occurrences of nordstrandite, gibbsite and todorokite are not new in the cave; they were firstly identified in the mineral deposits that are distributed on vent's roof and walls, at different locations of Sector Nord, Galeria del Tragus, Galeria de les Toberes, etc. (Merino et al., 2009; Fornós et al., 2011). The mineral assemblage of these extremely fluffy and porous materials is composed as well of strontianite, celestine, barite, chamosite and jacobsite, which along with the abundance of vertical feeders or vents, suggests a hypogene (thermal water related) basal recharge at various times during the evolution of the cave (Ginés et al., 2014, 2017; Onac et al., 2014).

The new discovered occurrences of nordstrandite (Table 4) exhibit a thin pinkish to reddish, brown to orange coloured coating, whereas gibbsite and todorokite are intermingled with other minerals, including phosphates, occurring as brown to black deposits. Specifically, at one locality, nordstrandite is accompanied by todorokite, birnessite, and calcite, or by illite, calcite, kaolinite, or quartz at others (Tables 3, 4). A thin layer of nordstrandite, illite and kaolinite is overlaying a nordstrandite and fluorapatite deposit that covers a fallen boulder. The vast majority of these mineral assemblages are deposited on fallen boulders or rock shelves (Table 4), but nordstrandite has also been identified at the bottom of an ovoidshaped feature, along with calcite, kaolinite and muscovite-illite. Only one occurrence of nordstrandite intermixed with fluorapatite, gibbsite, and calcite has been identified in a multicoloured ceiling deposit. The characteristics of the spots where these minerals mixtures occur, horizontal surfaces, or batrelated features, would reveal a certain connection 
with bats and guano deposits. Polyak (1998) and Polyak and Provencio (2001) identify, among others, nordstrandite, gibbsite and todorokite as a possible speleogenetic by-product formed as a consequence of the reaction between $\mathrm{H}_{2} \mathrm{SO}_{4}$ bearing waters and clay minerals (bedrock in the case of todorokite) with the participation of microorganisms and their by-products. Cova des Pas de Vallgornera does not present a $\mathrm{H}_{2} \mathrm{SO}_{4}$ speleogenetic vector along its evolution, being utterly devoid of $\mathrm{H}_{2} \mathrm{SO}_{4}$ speleogenetic features.

In this sense, and taking these points into consideration, the origin of the new occurrences of nordstrandite, gibbsite, and todorokite could be related with acidic leachings, specifically sulfuric acid, released from guano decomposition (boosted by microbial action) reacting with aluminium-rich clays to generate these aluminium hydroxides, or with the limestone bedrock enriched in manganese by earlier ascending hypogene flows (Merino et al., 2009; Fornós et al., 2010; Ginés et al., 2014, 2017; Onac et al., 2014), in the case of the hydrous manganese oxide.

As stated before, phosphates are the largest group of minerals reported in this article. After having taken and analysed more than 290 samples from all around the cave (including the 70 collected at the studied sites), only a total of 34 samples yielded phosphates. So far, phosphates have been only identified at places where bat-derived features and morphologies associated to guano deposits are present, being fluorapatite by far the most abundant. The widespread occurrence of fluorapatite would indicate that the agent providing fluorine would be present at all sites and with a proper concentration as to react with other minerals. Fluorapatite is associated with fossil bone and teeth deposits (Hill \& Forti, 1997; McFarlane \& Lundberg, 2018), with bat urine reacting with calcite crusts (Hill \& Forti, 1997; Onac \& Vereş, 2003), with bat guano deposits or with the existence of traces of fluorite in the bedrock (Hill \& Forti, 1997). The cave is developed in the carbonate rocks appertaining to the Reef Complex Unit (Pomar, 1991), with an age ranging from Upper Tortonian to Lower Messinian (Pomar et al., 1996; Fornós et al., 2002). The bedrock is predominantly composed of calcarenites (calcite 98.27\%, dolomite $1.73 \%)$, which locally presents some dolomitization (dolomite 98.2\%, calcite $1.3 \%$, quartz 0.5\%).This would rule out the influence of existing fluorite in the bedrock as $\mathrm{F}^{-}$provider. Currently, the only known important fossil bone deposit is situated at Galeria del Tragus relatively far away from the Jacuzzi site and far from the rest of locations; two bat species belonging to Rhinolophus and Pipistrellus genera were recovered from that deposit (Bover et al., 2014). In spite of the fact that the accumulation of bat bones during the use of the cave as breeding and nursery sites is likely, no bone remains have been found in any of the locations with bat-related morphologies. The wet environment of the cave would have caused a quick guano decomposition, provoking acidic conditions and the dissolution of bat bones, consequently supplying fluorine. Bat urine and guano accumulations could have also supplied part of the $\mathrm{F}^{-}$necessary to form fluorapatite or hydroxylapatite. However, we cannot exclude the influence of another agents that could have also been involved in the contribution of fluorine.

The cave gathers morphological and mineralogical evidences of deep hypogene recharge episodes (Ginés et al., 2009, 2014; Merino et al., 2009, 2011; Fornós et al., 2010, 2011; Onac et al., 2014) linked to the geothermal anomalies existing in the Llucmajor platform (López et al., 2006; López, 2007). In addition, current chemical analysis of the Llucmajor aquifer showed significant concentrations of F-. López (2007) carried out an extensive campaign of water sampling from drilled wells within the area; 9 samples out of the 21 studied yielded $\mathrm{F}^{-}$-concentrations above $200 \mu \mathrm{g} / \mathrm{L}$, whereas 3 of the 9 indicated concentrations of 1080 , 1170, and $1966 \mu \mathrm{g} / \mathrm{L}$. These ascending hypogene solutions might have also acted as $\mathrm{F}^{-}$carrier, reacting with already precipitated phosphates to produce fluorapatite.

A common secondary mineral associated with guano deposits is gypsum, but due to its high solubility, the moisture conditions present in the cave, the extensive vadose water accumulations fed by seeping waters, and the repeated inundation of the cave during the high-stand Pleistocene periods, most of the gypsum would have been removed. The only occurrence of gypsum is located at Galeria d'en Pau where it forms small saccharoid deposits.

\section{CONCLUSIONS}

The cave provided shelter for bat colonies until it was sealed by the collapse of its natural entrances around 2.4 My ago, it is highly likely it remained isolated from the outside until it was discovered in 1968. At present, it does not harbour any bat colonies.

The impact of ancient bat colonies in Cova des Pas de Vallgornera can be inferred by the discovery of the following ichnofossils, as well as morphologies related to guano deposits and associated cave minerals:

- bat claws and bat thumbs marks,

- morphologies present in lenticular cross-section niches and ovoid-shaped alcoves,

- haystack-shaped stalagmites and stalagmites covered in niches,

- crypto-corrosion features (flutes),

- guano-derived cave minerals (fluorapatite, hydroxylapatite).

All of this makes the cave an outstanding and unique site for cave mineralogy associated to guanoderived minerals and related morphologies. At the same time, the location of these bat-derived features along with the study of the microclimatic conditions that prevailed and prevail in the cave provide palaeoenvironmental information and can be used as indicators of bat ethology.

\section{ACKNOWLEDGEMENTS}

We are grateful to Philippe Audra for his extremely helpful comments of an early version of the manuscript. Our gratitude must also be extended to Augusto Auler 
and two anonymous reviewers for their suggestions and constructive comments, the incorporation of which greatly improved the article.

We are indebted to the Direcció General d'Espais Naturals i Biodiversitat del Govern de les Illes Balears for granting permission to perform research in the cave. This work is partially funded by the research grant MINECO CGL2016-79246-P. We thank Ferran Hierro and Joan Cifre of Serveis Cientifico-Tècnics de la UIB, for their support in analyzing the mineral samples. Finally, we greatly acknowledge the editor Jo De Waele for improving the English style as well as his suggestions.

\section{REFERENCES}

Audra P., Barriquand L., Bigot J.Y., Cailhol D., Caillaud H., Vanara N., Nobécourt J.C., Madonia G., Vattano M. \& Renda M., 2016 - L'impact méconnu des chauvessouris et du guano dans l'évolution morphologique tardive des cavernes. Karstologia, 68: 1-20.

Audra P., Barriquand L., Bigot J.Y., Cailhol D., Caillaud H., Vanara N., Nobécourt J.C., Madonia G. \& Vattano M., 2017 - The little-known impact of bats and bat guano in the stages of cave morphogenesis. Poster. 25 $5^{\text {th }}$ International Karstological School "Classical Karst". Milestones and Challenges in Karstology, Postojna, Slovenia.

Audra P., De Waele J., Bentaleb I., Chroňáková A., Krištůfek V., D’Angeli I.M., Carbone C., Madonia G., Vattano M., Scopelliti G., Cailhol D., Vanara N., Temovski M., Bigot J.-Y., Nobécourt J.-C., Galli E., Rull F. \& Sanz-Arranz A., 2019 - Guano-related phosphaterich minerals in European caves. International Journal of Speleology, 48 (1): 75-105.

https://doi.org/10.5038/1827-806X.48.1.2252

Baudinette R.V., Wells R.T., Sanderson K.J. \& Clark B., 1994 - Microclimatic conditions in maternity caves of the bent-wing bat, Miniopterus screibersii: an attemped restoration of a former maternity site. Wildlife Research, 21: 607-619. https://doi.org/10.1071/WR9940607

Bird M.I., Boobyer E.M., Bryant C., Lewis H.A., Paz V. \& Stephens W.E., 2007 - A long record of environmental change from bat guano deposits in Makangit Cave, Palawan, Philippines. Earth and Environmental Science Transactions of the Royal Society of Edinburgh, 98: 5969. https://doi.org/10.1017/S1755691007000059

Boop L.M., Onac B.P., Wynn J.G., Fornós J.J., Rodríguez-Homar M. \& Merino A., 2014 - Groundwater geochemistry observations in littoral caves of Mallorca (Western Mediterranean): implications for deposition of phreatic overgrowths on speleothems. International Journal of Speleology, 43 (2): 193-203.

https://doi.org/10.5038/1827-806X.43.2.7

Bover P., Valenzuela A., Guerra C., Rofes J., Alcover J.A., Ginés J., Fornós J.J., Cuenca-Bescós G. \& Merino A., 2014 - The Cova des Pas de Vallgornera (Llucmajor, Mallorca): a singular deposit bearing an exceptional well-preserved Early Pleistocene vertebrate fauna. International Journal of Speleology, 43 (2): 175-192. https://doi.org/10.5038/1827-806X.43.2.6

Conn H.W., 1966 - Barometric wind in Wind and Jewel Caves, South Dakota. National Speleological Society Bulletin, 28 (2): 55-59.

Dandurand G., Duranthon F., Jarry M., Stratford D.J. \& Bruxelles L., 2019 - Biogenic corrosion caused by bats in Drotsky's Cave (the Gcwihaba Hills, NW Botswana). Geomorphology, 327: 284-296.

https://doi.org/10.1016/j.geomorph.2018.10.027
Dreybrodt W., Gabrovšek F. \& Perne M., 2005 Condensation corrosion: a theoretical approach. Acta Carsologica, 34 (2): 317-348.

Fornós J.J., Pomar L. \& Ramos-Guerrero E., 2002 Balearic Islands. In: Gibbons W. \& Moreno T.T. (Eds.), The geology of Spain. Geological Society, London, p. 327-334.

Fornós J.J., Ginés A., Ginés J., Gràcia F., Merino A., Cifre J. \& Hierro F., 2010 - Hypogene speleogenetic evidences in the development of Cova des Pas de Vallgornera (Mallorca Island, Western Mediterranean). In: Andreo B., Carrasco F., Durán J.J. \& LaMoreaux J.W. (Eds.), Advances in research in karst media. Springer-Verlag, Environmental Earth Sciences Series, Berlin, p. 349-354.

https://doi.org/10.1007/978-3-642-12486-0_54

Fornós J.J., Merino A., Ginés J., Ginés A. \& Gràcia F., 2011 - Solutional features and cave deposits related to hypogene speleogenetic processes in a littoral cave of Mallorca Island (western Mediterranean). Carbonates and Evaporites, 26 (1): 69-81. https://doi.org/10.1007/s13146-010-0040-3

Ginés J., Ginés A., Fornós J.J., Merino A. \& Gràcia F., 2009 - On the role of hypogene speleogenesis in shaping the coastal endokarst of southern Mallorca (Western Mediterranean). In: Klimchouk A.B. \& Ford D.C. (Eds.) Hypogene speleogenesis and karst hydrogeology of artesian basins. Ukrainian Institute of Speleology and Karstology, Simferopol. Special Paper, 1, p. 91-99.

Ginés J., Fornós J.J., Ginés A., Merino A. \& Gràcia F., 2014 -Geologic constraints and speleogenesis of Cova des Pas de Vallgornera, a complex coastal cave from Mallorca Island (Western Mediterranean). International Journal of Speleology, 43 (2): 105-124.

https://doi.org/10.5038/1827-806X.43.2.2

Ginés J., Fornós J.J., Gràcia F., Merino A. Onac B.P. \& Ginés A., 2017 - Hypogene imprints in coastal karst caves from Mallorca Island (Western Mediterranean): Morphological features and speleogenetic approach. In: Klimchouk A., Palmer A.N., De Waele J., Auler A.S. \& Audra P. (Eds.), Hypogene karst regions and caves of the world. Springer, Cham, p. 99-112. https://doi.org/10.1007/978-3-319-53348-3 5

Giurgiu A. \& Tămaş T., 2013 - Mineralogical data on bat guano deposits from three Romanian caves. Studia UBB Geologia, 58 (2): 13-18. https://doi.org/10.5038/1937-8602.58.2.2

Gràcia F., Fornós J.J., Gamundí P., Clamor B. \& Pocoví J., 2009a - Morfologies de corrosió a la part submergida de la Cova des Pas de Vallgornera. Sector Antic, Sector de Gregal i Sector de les Grans Sales. Endins, 33: 73-98.

Gràcia F., Fornós J.J. \& Merino A., 2009b - Corrosion patterns related to meteoric-marine mixing zones in coastal cave systems of Mallorca island (Western Mediterranean). In: White W.B. (Ed.), Proceedings of the $15^{\text {th }}$ International Congress of Speleology. National Speleological Society, Kerrville, 1, p. 496-500.

Hill C.A. \& Forti P., 1997 - Cave minerals of the world ( $2^{\text {nd }}$ Ed.). National Speleological Society, Huntsville, Alabama, $464 \mathrm{p}$.

Just J., Hübscher C., Betzler C., Lüdmann T. \& Reicherter K., 2011-Erosion of continental margins in the Western Mediterranean due to sea-level stagnancy during the Messinian Salinity Crisis.Geo-Marine Letters, 31: 51-64. https://doi.org/10.1007/s00367-010-0213-Z

López J.M., 2007 - Las manifestaciones hidrotermales del sur de Llucmajor, Mallorca. Memòria d'Investigació, Departament de Ciències de la Terra, Universitat de les Illes Balears, Unpublished, 132 p. 
López J.M. \& Mateos R.M., 2006 - Control estructural de las anomalias geotérmicas y la intrusión marina en la plataforma de Llucmajor y la cubeta de Campos (Mallorca). Las aguas subterráneas en los países mediterráneos. Instituto Geológico y Minero de España, Madrid. Serie Hidrogeología y Aguas Subterráneas, 17: 607-613.

López J.M., Mateos R.M. \& Ballester A., 2004 Aportaciones del sondeo de investigación geotérmica Lluis Moragues al modelo de funcionamiento hidrogeológico de las aguas termales de la plataforma de Llucmajor (Mallorca). VIII Simposio de Hidrogeología, Zaragoza, 2: 379-388.

Lorscheid T., Stocchi P., Casella E., Gómez-Pujol L., Vacchi M., Mann T. \& Rovere A., 2017 - Paleo sealevel changes and relative sea-level indicators: Precise measurements, indicative meaning and glacial isostatic adjustment perspectives from Mallorca (Western Mediterranean). Palaeogeography, Palaeoclimatology, Palaeoecology, 473: 94-107.

https://doi.org/10.1016/j.palaeo.2017.02.028

Lundberg J. \& McFarlane D.A., 2008 - Bats and bell holes: The microclimatic impact of bat roosting, using a case study from Runaway Bay Caves, Jamaica. Geomorphology, 106: 78-85.

https://doi.org/10.1016/j.geomorph.2008.09.022

Lundberg J. \& McFarlane D.A., 2015 - Microclimate and niche constructionism in tropical bat caves: A case study from Mount Elgon, Kenya. In: Feinberg J., Gao Y. \& Alexander E.C. Jr. (Eds.), Caves and karst across time. Geological Society of America Special Paper, 516: 211219. https://doi.org/10.1130/2015.2516(17)

Marincea Ş., Dumitraş D-G., Diaconu G. \& Bilal E., 2004 - Hydroxylapatite, brushite and ardealite in the bat guano deposit from Peştera Mare de la Mereşti, Perşani Mountains, Romania. Neues Jahrbuch für MineralogieMonatshefte, 2004 (10): 464-488.

https://doi.org/10.1127/0028-3649/2004/2004-0464

Mateos R.M., López J.M. \& Sánchez-Guzmán J., 2005 Most recent explorations projects in Spain. Geothermal research of the Llucmajor area, Mallorca (Balearic Islands). IGA News, 62: 4-7.

McFarlane D.A. \& Lundberg J., 2018 - New records of guano-associated minerals from caves in northwestern Borneo. International Journal of Speleology, 47 (2): 119 126. https://doi.org/10.5038/1827-806X.47.2.2169

McNab B.K., 1982 - Evolutionary alternatives in the physiological ecology of bats. In: Kunz T.H. (Ed.), Ecology of bats. New York, Plenum Press, p. 151-200. https://doi.org/10.1007/978-1-4613-3421-7_4

Merino A., Fornós J.J. \& Onac B.P., 2009 - Preliminary data on mineralogical aspects of cave rims and vents in Cova des Pas de Vallgornera, Mallorca. In: White W.B. (Ed.), Proceedings of the $15^{\text {th }}$ International Congress of Speleology. National Speleological Society, Kerrville, 1, p. 307-311.

Merino A., Ginés J. \& Fornós J.J., 2011 -Evidències morfològiques de processos hipogènics a cavitats de Mallorca. Endins, 35: 165-182.

Merino A., Mulet A., Mulet G., Croix A., Kristofersson A., Gràcia F. \& Perelló M.A., 2014a - Cova des Pas de Vallgornera (Mallorca, Spain): History of exploration and cave description. International Journal of Speleology, 43 (2): 95-104.

https://doi.org/10.5038/1827-806X.43.2.1

Merino A., Ginés J., Tuccimei P., Soligo M. \& Fornós J.J., 2014b - Speleothems in Cova des Pas de Vallgornera: their distribution and characteristics within and extensive coastal cave from the eogenetic karst of southern Mallorca (Western Mediterranean). International Journal of Speleology, 43 (2): 125-142. https://doi.org/10.5038/1827-806X.43.2.3

Onac B.P. \& Veres D.S., 2003 - Sequence of secondary phosphates deposition in a karst environment: evidence from Magurici Cave (Romania). European Journal of Mineralogy, 15: 741-745.

https://doi.org/10.1127/0935-1221/2003/0015-0741

Onac B.P., Fornós J.J., Ginés A. \& Ginés J., 2005 Mineralogical reconnaissance of caves from Mallorca Island. Endins, 27: 131-140.

Onac B.P., Sumrall J., Mylroie J.E. \& Kearns J.B., 2009 - Cave minerals of San Salvador Island, Bahamas. The University of South Florida Karst Studies Series 1, 69 p. Onac B.P., Fornós J.J., Merino A., Ginés J. \& Diehl J., 2014 - Linking mineral deposits to speleogenetic processes in Cova des Pas de Vallgornera (Mallorca, Spain). International Journal of Speleology, 43 (2): 143-157. https://doi.org/10.5038/1827-806X.43.2.4

Pflitsch A. \& Piasecki J., 2003 - Detection of an airflow system in Niedzwiedzia (bear) Cave, Kletno, Poland. Journal of Cave and Karst Studies, 65 (3): 160-173. http://ww.caves.org/pub/journal/PDF/V65/v65n3Pflitsch.pdf

Pflitsch A., Wiles M., Horrocks R., Piasecki J. \& Ringeis J., 2010 - Dynamic climatologic process of barometric cave systems using the example of Jewel Cave and Wind Cave, in South Dakota, USA. Acta Carsologica, 39 (3): 449-462.

https://doi.org/10.3986/ac.v39i3.75

Pogson R.E., Osborne R.A.L. \& Colchester D.M., 2014 Minerals of Jenolan Caves, New South Wales, Australia: Geological and biological interactions. Proceedings of the Linnean Society of New South Wales, 136: 1-18.

Polyak V.J., 1998 - Clays and associated minerals in caves of the Guadalupe Mountains, New Mexico. Unpublished PhD Thesis), Texas Tech University, 190 p.

Polyak V.J. \& Provencio P., 2001 - By-product materials related to $\mathrm{H}_{2} \mathrm{~S}-\mathrm{H}_{2} \mathrm{SO}_{4}$ influenced speleogenesis of Carlsbad, Lechuguilla, and other caves of the Guadalupe Mountains, New Mexico. Journal of Cave and Karst Studies, 63: 23-32.

http://ww.caves.org/pub/journal/PDF/V63/v63n1Polyak.pdf

Pomar L., 1991 - Reef geometries, erosion surfaces and high-frequency sea-level changes, Upper Miocene Reef Complex, Mallorca, Spain. Sedimentology, 38: 243-269. https://doi.org/10.1111/j.1365-3091.1991.tb01259.x

Pomar L. \& Ward W.C., 1995 - Sea-level changes, carbonate production and platform architecture: the Llucmajor Platform, Mallorca, Spain. In: Haq B.U. (Ed.), Sequence stratigraphy and depositional response to eustatic, tectonic and climatic forcing. Springer, Dordrecht, p. 87-112.

https://doi.org/10.1007/978-94-015-8583-5_4

Pomar L., Ward W.C. \& Green D.G., 1996-Upper Miocene reef complex of the Llucmajor area, Mallorca, Spain. In: Franseen E., Esteban M., Ward W.C. \& Rouchy J.M. (Eds.), Models for carbonate stratigraphy from Miocene reef complexes of the Mediterranean regions. SEPM Concepts in Sedimentology and Paleontology, 5: 191225. https://doi.org/10.2110/csp.96.01.0191

Puşcaş C.M., Kristaly F., Stremțan C.C., Onac B.P. \& Effenberger H.S., 2014 - Stability of cave phosphates: Case study from Liliecilor Cave (Trascău Mountains, Romania). Neues Jahrbuch für Mineralogie-Abhandlungen: Journal of Mineralogy and Geochemistry, 191 (2): 157-168.

https://doi.org/10.1127/0077-7757/2014/0254 
Ransome R., 1990 - The natural history of hibernating bats. Christopher Helm, London, 235 p.

Raymo M.E., Kozdon R., Evans D., Lisiecki L. \& Ford H.L., 2018 - The accuracy of mid-Pliocene $\mathrm{\delta}^{18} \mathrm{O}$-based ice volume and sea level reconstructions. Earth ScienceReviews, 177: 291-302.

https://doi.org/10.1016/j.earscirev.2017.11.022

Rodrigues L. \& Palmeirin J.M., 2008 - Migratory behaviour of the Schreiber's bat: when, where and why do cave bats migrate in a Mediterranean region? Journal of Zoology, 274: 116-125.

https://doi.org/10.1111/j.1469-7998.2007.00361.x

Serra-Cobo J., Bayer X., López-Roig M. \& Seguí M., 2011 - Les ratapinyades de les Illes Balears: Distribució, avaluació $i$ estat sanitari de les poblacions. Endins, 35/Monografies de la Societat d'Història Natural de les Balears, 17: 269-282.
Serra-Cobo J. \& López-Roig M., 2015 - Estudis ecoepidemiològics de quiròpters a les Illes Balears. Monografies de la Societat d'Història Natural de les Balears, 20: 333-341.

Tarhule-Lips R.F.A. \& Ford D.C., 1998 - Morphometric studies of bell hole development on Cayman Brac. Cave and Karst Science, 25 (3): 119-130.

Wurster C.M., McFarlane D.A., Bird M.I., Ascough P. \& Athfield N.B., 2010 - Stable isotopes of subfossil bat guano as a long-term environmental archive: insights from a Grand Canyon cave deposit. Journal of Cave and Karst Studies, 72: 111-121. https://doi.org/10.4311/jcks2009es0109

Wurster C.M., Munksgaard N., Zwart C. \& Bird M., 2015 The biogeochemistry of insectivorous cave guano: a case study from insular Southeast Asia. Biogeochemistry, 124 (1-3): 163-175.

https://doi.org/10.1007/s10533-015-0089-0 